\title{
A vitronectin-derived peptide reverses ovariectomy-induced bone loss via regulation of osteoblast and osteoclast differentiation
}

\author{
Seung-Ki Min ${ }^{1,3}$, Hyun Ki Kang ${ }^{2,3}$, Sung Youn Jung ${ }^{2,3}$, Da Hyun Jang ${ }^{2}$ and Byung-Moo Min ${ }^{\star, 2}$
}

Osteoporosis affects millions of people worldwide by promoting bone resorption and impairing bone formation. Bisphosphonates, commonly used agents to treat osteoporosis, cannot reverse the substantial bone loss that has already occurred by the time of diagnosis. Moreover, their undesirable side-effects, including osteonecrosis of the jaw, have been reported. Here, we demonstrated that a new bioactive core vitronectin-derived peptide (VnP-16) promoted bone formation by accelerating osteoblast differentiation and activity through direct interaction with $\beta 1$ integrin followed by FAK activation. Concomitantly, VnP-16 inhibited bone resorption by restraining JNK-c-Fos-NFATc1-induced osteoclast differentiation and $\alpha v \beta 3$ integrin-c-Src-PYK2-mediated resorptive function. Moreover, $\mathrm{VnP}-16$ decreased the bone resorbing activity of pre-existing mature osteoclasts without changing their survival rate. Furthermore, $\mathrm{VnP}-16$ had a strong anabolic effect on bone regeneration by stimulating osteoblast differentiation and increasing osteoblast number, and significantly alleviated proinflammatory cytokine-induced bone resorption by restraining osteoclast differentiation and function in murine models. Moreover, VnP-16 could reverse ovariectomy-induced bone loss by both inhibiting bone resorption and promoting bone formation. Given its dual role in promoting bone formation and inhibiting bone resorption, our results suggest that $\mathrm{VnP}-16$ could be an attractive therapeutic agent for treating osteoporosis.

Cell Death and Differentiation (2018) 25, 268-281; doi:10.1038/cdd.2017.153; published online 22 September 2017

Bone defects that result from fractures, accidents, cancer, or other diseases pose a serious risk of loss of function and can significantly impair quality of life. ${ }^{1}$ Current grafting methods have limitations such as donor site morbidity and graft rejection. ${ }^{2,3}$ Osteoporosis is a systematic skeletal disorder characterized by low bone mass, microarchitectural deterioration of bone tissue, and susceptibility to fracture. ${ }^{4-6}$ Furthermore, the incidence of osteoporosis is very high and has increased due to ageing of populations worldwide, which is responsible for a growing number of postmenopausal women with osteoporosis. ${ }^{7,8}$ More improved bone formation method such as new therapeutic agents is highly in demand because many patients with osteoporosis followed by fractures still end up with poor clinical outcomes after the current surgery and techniques for bone healing. ${ }^{9}$

Proteins are of major concern in the field of tissue engineering because of their exquisite potency and selectivity for their molecular targets. ${ }^{10}$ Although the functions and potential applications of several proteins in bone engineering have been described, ${ }^{11}$ the use of proteins for therapeutics is associated with high cost and a number of other disadvantages. ${ }^{12}$ Because of their flexibility in adopting and mimicking the local structural features of proteins, ${ }^{13}$ peptides are a valid alternative. ${ }^{14}$ Furthermore, the use of peptides in regenerative medicine has several advantages over the use of entire proteins in terms of immunogenicity, susceptibility to degradation, and tumor-related side effects. ${ }^{15-17}$ To date, local application of numerous peptides has been used to repair bone defects in the clinic; however, very few peptides have the ability to form bone themselves. ${ }^{13}$ On the other hand, a few peptide drugs derived from protein hormones such as calcitonin gene-related peptide ( $\alpha$-CGRP; 37-mer) and parathyroid hormone 1-34 peptide (teriparatide) have shown clinical usefulness for treating osteopenia/osteoporosis and calcium homeostasis disorders. ${ }^{13}$ Among their functions, $a$ CGRP inhibits bone resorption by inhibiting nuclear factor kappa B (NF-kB) activity whereas teriparatide increases bone mass by stimulating bone formation via promoting osteoblast proliferation and differentiation and preventing its apoptosis. ${ }^{13,18}$ However, a concern has been raised about the potential risk of osteosarcoma in patients who have used teriparatide as high percentage of the rats treated with high dose of it shows osteosarcoma. ${ }^{19}$

Normal bone mass and architecture are maintained by osteoclasts and osteoblasts, and bone is continuously renewed through a dynamic balance between resorption and formation. An imbalance caused by the increased activity and/ or number of osteoclasts leads to bone destruction in pathological bone diseases; ${ }^{4}$ therefore, much focus has been placed on the pharmacological control of osteoclasts for the treatment of osteoclast-related bone disorders such as osteoporosis and arthritis. ${ }^{5,6}$ Osteoclastogenesis is cooperatively induced by macrophage-colony stimulating factor (M-CSF), receptor activator of NF-kB ligand (RANKL), and its

${ }^{1}$ Oral Oncology Clinic, Research Institute and Hospital, National Cancer Center, Goyang-Si, Gyeonggi-Do 10408, Republic of Korea and ${ }^{2}$ Department of Oral Biochemistry and Program in Cancer and Developmental Biology, Dental Research Institute, Seoul National University School of Dentistry, Seoul 03080, Republic of Korea

${ }^{*}$ Corresponding author: B-M Min, Department of Oral Biochemistry and Program in Cancer and Developmental Biology, Seoul National University School of Dentistry, 101 Daehak-Ro, Jongno-Gu, Seoul 03080, Republic of Korea. Tel: +82 2740 8661; Fax: +82 2740 8665; E-mail: bmmin@snu.ac.kr

${ }^{3}$ These authors contributed equally to this work.

Received 01.5.17; revised 01.8.17; accepted 17.8.17; Edited by P Bouillet; published online 22.9.17 
co-stimulatory factor. ${ }^{20-22}$ RANKL induces entire processes that promote the development of osteoclasts. ${ }^{23,24}$ Specifically, RANKL activates the three mitogen-activated protein kinases (MAPKs), leading to the activation of downstream regulators of osteoclast formation, including c-Fos and nuclear factor of activated T cells, cytoplasmic 1 (NFATc1), both of which are master regulators of osteoclast differentiation. ${ }^{20-22,25}$ NFATc1 regulates a number of osteoclast-specific genes in cooperation with other transcription factors. ${ }^{26}$ cAMP-response element-binding protein also cooperates with NFATc1 to activate these genes. ${ }^{27}$ The roles of NFATc1 in osteoclastogenesis have been demonstrated in vitro and in vivo. ${ }^{25,28,29}$ Furthermore, proline-rich tyrosine kinase 2 (PYK2) forms a complex with c-Src, linking $a v \beta 3$ integrin signaling to actin cytoskeletal organization in osteoclasts. ${ }^{30}$

Vitronectin, an abundant multifunctional glycoprotein found in serum, the extracellular matrix, and bone ${ }^{31}$ is involved in various physiological processes and promotes cell attachment, spreading, and migration. ${ }^{32,33}$ Here, we developed a new vitronectin-derived therapeutic peptide named $\mathrm{VnP}-16$ (RVYFFKGKQYWE; residues 270-281) that promotes osteoblast differentiation and activity, and concomitantly restrains osteoclast differentiation and resorptive function. We elucidated the mechanism by which VnP-16 exhibits opposite effects on osteoblast and osteoclast differentiation, and its biological potency on bone formation and resorption, in three different, but complementary, animal models.

\section{Results}

A human vitronectin-derived peptide promotes osteogenic cell behavior. To identify the biologically active sequences that confer bone-forming activity, three constructs covering the entire human vitronectin protein were generated (rVn-FI, rVn-FII, and rVn-FIII; Figure 1a), expressed separately in Escherichia coli (Figure 1b), and characterized (Figures 1c and d). Characterization of the bacterially expressed rVn truncations showed the presence of intramolecular disulfide bonds in all three recombinant proteins (Figure 1c) and protein rich in $\beta$-structure (Figure 1d), suggesting their sufficiency in folding. Furthermore, analyses of $r V n$ truncations showed their ability to perform cell behavior, except rVn-FIII (Figures 1e-h). Even though rVnFI was the most biologically active of the three recombinant truncations (Figures $1 \mathrm{f}-\mathrm{h}$ ), however, we focused on identifying the bioactive cell binding sequences required for this activity of rVn-FII, because peptides lacking the RGD motif within the $\mathrm{rVn}-\mathrm{FI}$ region did not show cell attachment and spreading activities (data not shown).

A series of overlapping 12-mer peptides (VnP-11 to VnP-21) covering the rVn-FII truncation (amino acids 230-322), which contained two $\alpha$-helices and nine $\beta$-strands (Supplementary Figure S1), was synthesized (Figure 2a). Human osteogenic cells that were differentiated from skin-derived precursors (SKPs) were used to test the functions and osteoinductive activities of the synthetic peptides. Directed differentiation from SKPs to mesenchymal precursors to osteogenic cells is shown in Supplementary Figure S2. VnP-16 promoted the cell attachment activity of osteogenic cells in a dose-dependent manner, and its activity reached a maximum at a concentration of approximately $9.1 \mu \mathrm{g} / \mathrm{cm}^{2}$ (Figures $2 \mathrm{~b}$ and c). $\mathrm{VnP}-16$ also induced cell spreading to an extent that was comparable to that of vitronectin (Figure 2d), but did not affect the viability of the osteogenic cells (Figure 2e). Next, to determine the minimum bioactive sequence, synthetic peptides were prepared from $\mathrm{VnP}-16$, which are $\mathrm{N}$ - and $\mathrm{C}$-terminal truncated peptides (Figure 2f). Further deletion in $\mathrm{VnP}-16$ led to significantly lower cell attachment than that of $\mathrm{VnP}-16$ (Figure 2g), demonstrating that $\mathrm{VnP}-16$ is a bioactive core binding sequence for cellular responses. We further investigated whether $\mathrm{VnP}-16$ could also mediate the attachment of other types of cells. Notably, $\mathrm{VnP}-16$ enhanced the attachment of primary fibroblasts, including normal human dermal fibroblasts (NHDFs) and normal human oral fibroblasts (NHOFs), and fibroblast lineages, including MC3T3-E1 and $\mathrm{NIH} / 3 \mathrm{~T} 3$ cells, but not that of other cell types, including normal human epidermal keratinocytes (NHEKs) and normal human oral keratinocytes (NHOKs; Figure $2 \mathrm{~h}$ ). These results demonstrate that $\mathrm{VnP}-16$ acts via a fibroblast lineage-specific attachment mechanism. In addition, VnP-16 did not affect the viabilities of the fibroblasts (Supplementary Figure S3), indicating that it is cytocompatible. The PSIPRED protein structure prediction server identified two $\beta$-strands in the VnP-16 (Figure 2i). Taken together, these data demonstrate that $\mathrm{VnP}-16$ is a bioactive core binding sequence that acts on fibroblast lineage cells, including human osteogenic cells, but not on normal human keratinocytes.

B1 integrin mediates VnP-16-induced osteogenic cell attachment. Next, we examined which specific adhesion receptor for $\mathrm{VnP}-16$ mediates cell attachment in human osteogenic cells. Cell attachment to $\mathrm{VnP}-16$ was not inhibited by heparin (Figure 3a), suggesting that the cell surface proteoglycan receptor is not the receptor for $\mathrm{VnP}-16$. Because binding of integrins and $a$-dystroglycan to their ligands requires a divalent cation such as $\mathrm{Ca}^{2+}$ or $\mathrm{Mn}^{2+},{ }^{34}$ we investigated the effect of EDTA, a metal-chelating reagent, on cell attachment to $\mathrm{VnP}-16$. Pretreatment of osteogenic cells with EDTA inhibited their attachment to VnP-16 completely, whereas treatment with $\mathrm{Mn}^{2+}$ enhanced cell attachment significantly (Figure 3a). Investigation of the effects of integrin subunit-blocking antibodies on cell attachment to $\mathrm{VnP}-16$ revealed a significant inhibitory effect of a $\beta 1$-blocking antibody (Figure $3 b$ ). $\beta 3$ integrin also plays a key role in cell attachment and migration; ${ }^{35}$ however, it was not involved in VnP-16-mediated osteogenic cell attachment. Furthermore, suppression of $\beta 1$ integrin expression by transfection of cells with a $\beta 1$ integrin-specific small interfering RNA (siRNA; Figures $3 c$ and $d$ ) inhibited cell attachment to $\mathrm{VnP}-16$ significantly (Figure 3e). Next, to further explore whether $\mathrm{VnP}-16$ directly binds to and activates cell surface $\beta 1$ integrins, we cultured human osteogenic cells on biotinylated VnP-16-coated dishes for $30 \mathrm{~min}$, performed a pulldown assay with streptavidin beads, and then measured the level of $\beta 1$ integrin by immunoblotting. Biotinylated $\mathrm{VnP}-16$ directly bound to cell surface $\beta 1$ integrins (Figure $3 f)$. These data indicate that $\beta 1$ integrin functions as a major surface receptor for $\mathrm{VnP}-16$ in human osteogenic cells. 
a
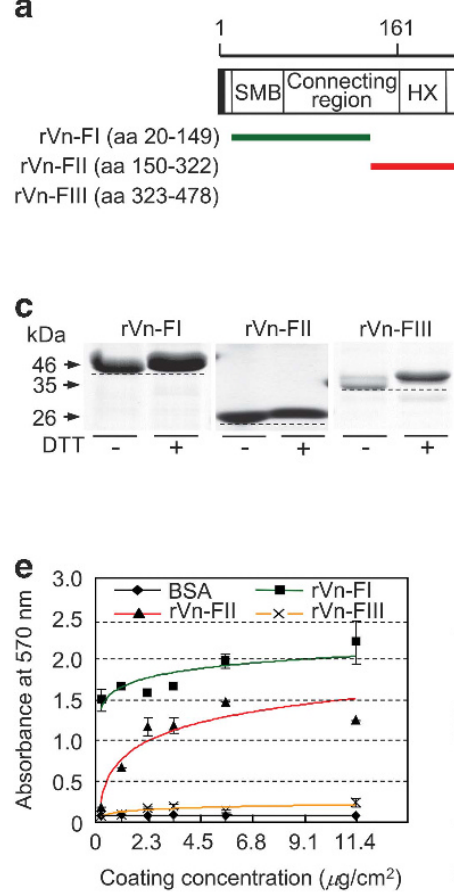

\begin{tabular}{|l|l|l|l}
\multicolumn{2}{|c|}{304} & \multicolumn{2}{|c}{478 (aa) } \\
\hline HX & & HX & domain \\
\hline
\end{tabular}

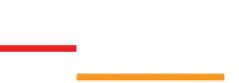

b Thioredoxin $\mathrm{His}_{6}$
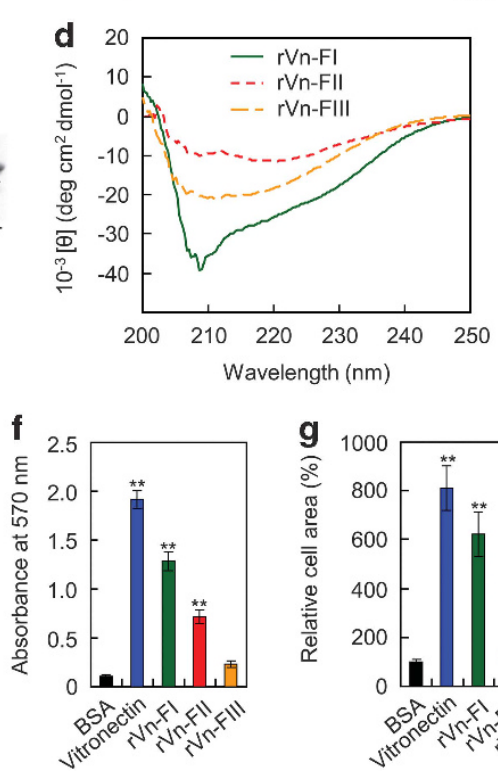

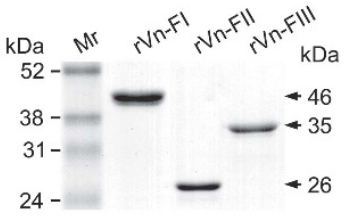

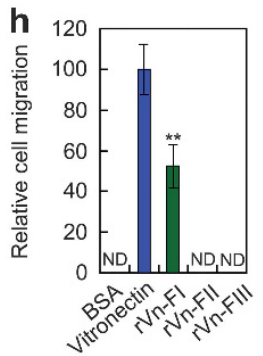

Figure 1 Analyses of purified rVn truncations by SDS-PAGE and circular dichroism spectroscopy and their effects on cell behavior. (a) Schematic diagram of the rVn truncations. The amino acid (aa) positions and the domain structure of full-length vitronectin are indicated. The black box and colored bars represent the signal peptide and the positions of the recombinant proteins, respectively. (b) Schematic diagram and SDS-PAGE analyses (10\% polyacrylamide gels under reducing conditions) of the purified rVn

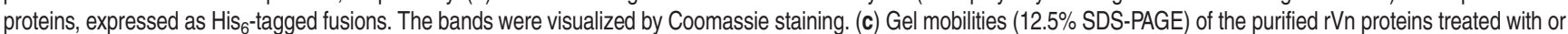
without dithiothreitol (DTT). (d) Circular dichroism analysis of the rVn fragments in PBS (pH 3.0) at $23^{\circ} \mathrm{C}$. (e) The dose-dependent effects of the truncated rVn proteins on the attachment of human osteogenic cells. The cells were seeded onto $\mathrm{rVn}$-treated plates for $1 \mathrm{~h}$ in serum-free medium. (f and $\mathbf{g})$ Cell attachment (f) and spreading $(\mathbf{g})$ of osteogenic cells induced by BSA (1\%), vitronectin $\left(0.23 \mu \mathrm{g} / \mathrm{cm}^{2}\right)$, and the truncated rVn proteins $\left(5.7 \mu \mathrm{g} / \mathrm{cm}^{2}\right)$ for $1 \mathrm{~h}(\mathrm{f})$ or $3 \mathrm{~h}(\mathrm{~g})$ in serum-free medium. (h) Migration of osteogenic cells induced by vitronectin and the truncated $\mathrm{rnn}$ proteins. Osteogenic cells were seeded into the upper chambers of Transwell filters coated with vitronectin or $\mathrm{r} V n$ proteins and were incubated for $24 \mathrm{~h}$. ND, not detected. Data in $(e-h)$ represent the mean $\pm \operatorname{SD}(n=4)$. ${ }^{*} P<0.01$

FAK activation plays an essential role in osteoblast differentiation. To investigate the downstream pathways stimulated by $\mathrm{VnP}-16 / \beta 1$ integrin-mediated signaling, we examined whether binding of $\mathrm{VnP}-16$ to osteogenic cells induced FAK activation. Compared with that in vehicle- or scrambled peptide (SP)-treated control cells, the levels of FAK phosphorylation at Tyr-397 and -577 were higher after VnP-16-mediated attachment and spreading of osteogenic cells; however, the levels of phospho-FAK Tyr-407, -576, and -861 were retained at basal levels (Figures $4 a$ and b). Because FAK Tyr397 is an autophosphorylation site that promotes interaction with c-Src or Fyn, ${ }^{36}$ we also measured the expression level of phospho-c-Src. The level of phosphoc-Src Tyr416 was increased in vitronectin- or VnP-16-treated cells, but those of phospho-Akt Ser473 and phospho-PKC $\delta$ Thr505 were not (Figures $4 a$ and b), suggesting that FAK phosphorylation at Tyr-397 and -577 , and c-Src phosphorylation at Tyr416 are linked to $\mathrm{VnP}-16 / \beta 1$ integrin-mediated signaling. Furthermore, cell attachment to $\mathrm{VnP}-16$ was inhibited in a dose-dependent manner by pretreatment of the cells with PF-573228 (Figures 4c-e), a known FAK inhibitor that effectively blocks phosphorylation of the protein at Tyr397. ${ }^{37}$
To assess the effects of $\mathrm{VnP}-16$ on osteoblast differentiation, osteoblast precursors and osteogenic cells were cultured in osteogenic differentiation medium containing $\mathrm{VnP}-16$ or SP. $\mathrm{VnP}-16$ increased the alkaline phosphatase activity and calcium deposition in the osteoblast precursors (Figure 4f), indicating that $\mathrm{VnP}-16$ promotes osteoblast differentiation. Next, to investigate the role of FAK phosphorylation at Tyr397 on osteoblast differentiation, osteoblast precursors and osteogenic cells were cultured on $\mathrm{VnP}$-16-treated plates in osteogenic differentiation medium containing PF-573228 or vehicle alone. PF-573228 reduced the alkaline phosphatase activity and calcium deposition in the osteoblast precursors (Figure $4 \mathrm{~g}$ ), indicating that the suppression of FAK phosphorylation at Tyr397 inhibits osteoblast differentiation. In addition, PF-573228 did not affect cell growth at the concentrations and incubation times used here (data not shown), excluding the possibility that the observed inhibition of cell attachment to $\mathrm{VnP}-16$ was caused by general cytotoxicity. Furthermore, suppression of FAK expression using a specific siRNA inhibited cell attachment to $\mathrm{VnP}-16$ significantly, whereas a control siRNA did not (Figures $4 \mathrm{~h}-\mathrm{j}$ ). On the other hand, $\mathrm{VnP}-16$ did not affect the apoptosis of the osteogenic cells at the concentration $\left(9.1 \mu \mathrm{g} / \mathrm{cm}^{2}\right)$ that promoted osteogenic cell 
a

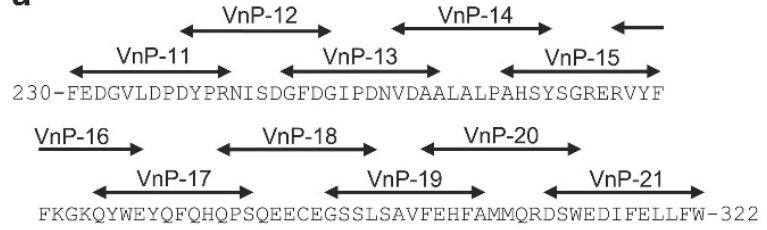

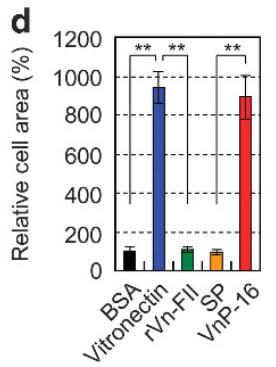
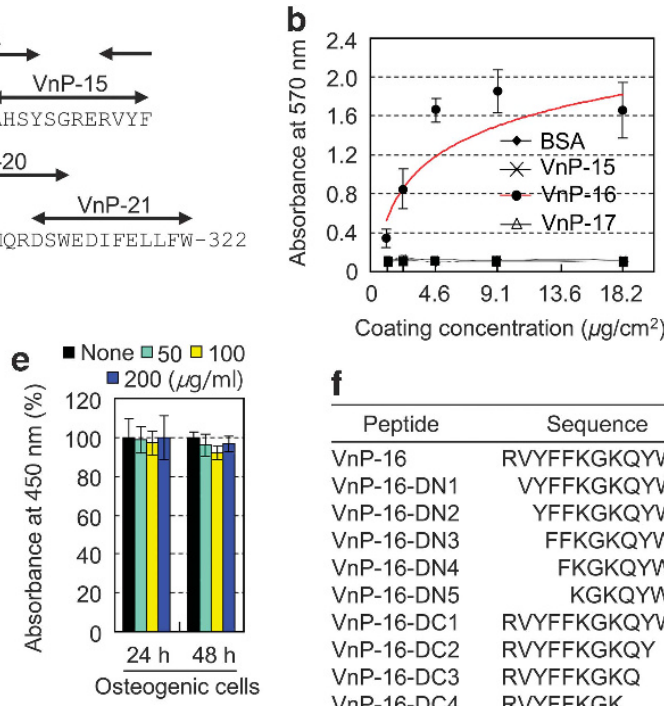

Coating concentration $\left(\mu \mathrm{g} / \mathrm{cm}^{2}\right)$
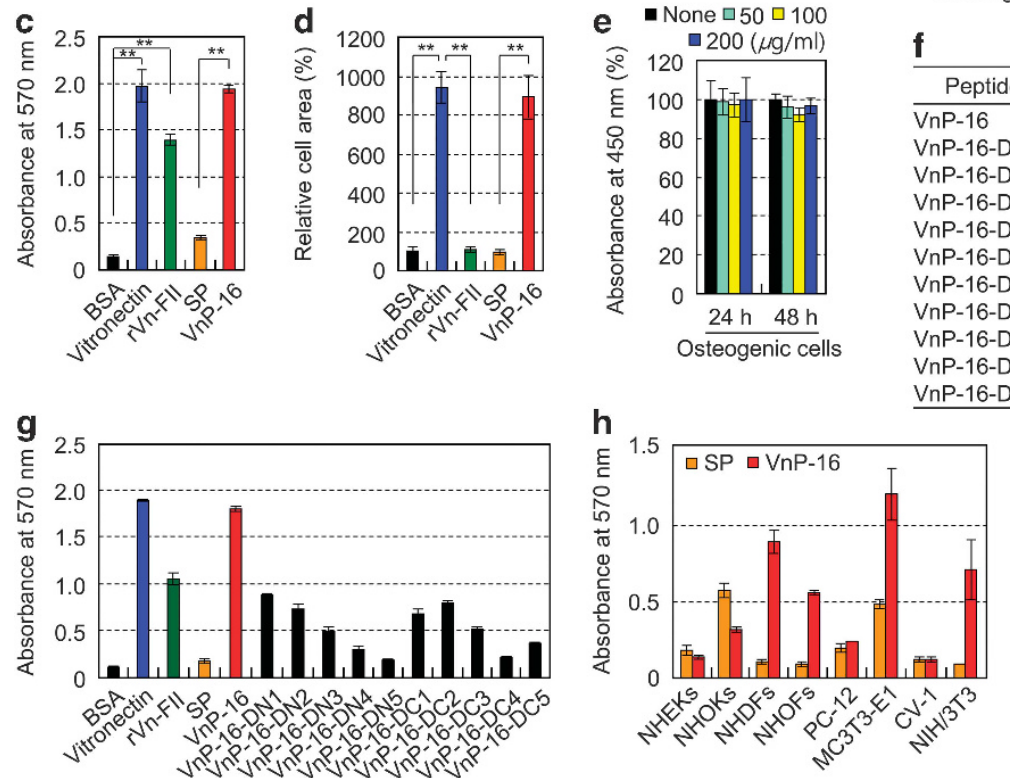

f

\begin{tabular}{lc}
\hline \multicolumn{1}{c}{ Peptide } & Sequence \\
\hline VnP-16 & RVYFFKGKQYWE \\
VnP-16-DN1 & VYFFKGKQYWE \\
VnP-16-DN2 & YFFKGKQYWE \\
VnP-16-DN3 & FFKGKQYWE \\
VnP-16-DN4 & FKGKQYWE \\
VnP-16-DN5 & KGKQYWE \\
VnP-16-DC1 & RVYFFKGKQYW \\
VnP-16-DC2 & RVYFFKGKQY \\
VnP-16-DC3 & RVYFFKGKQ \\
VnP-16-DC4 & RVYFFKGK \\
VnP-16-DC5 & RVYFFKG \\
\hline &
\end{tabular}

Figure 2 VnP-16 promotes cell behavior in fibroblast lineages. (a) The locations of the synthetic peptides (VnP-11 to VnP-21) in the amino acid sequence of the central region of human vitronectin (residues 230-322). (b) Dose-dependent cell attachment to immobilized synthetic peptides. Human osteogenic cells were allowed to adhere to peptidetreated plates for $1 \mathrm{~h}$ in serum-free medium. (c and $\mathbf{d})$ Cell attachment (c) and spreading (d) of osteogenic cells induced by treatment with BSA $(1 \%)$, vitronectin $\left(0.23 \mu \mathrm{g} / \mathrm{cm}^{2}\right)$, rVn-FIl $\left(5.7 \mu \mathrm{g} / \mathrm{cm}^{2}\right)$, or the synthetic peptides $\left(9.1 \mu \mathrm{g} / \mathrm{cm}^{2}\right)$ for $1 \mathrm{~h}$ (c) or $3 \mathrm{~h}$ (d) in serum-free medium. (e) The viabilities of osteogenic cells treated with VnP-16 for $24 \mathrm{or} 48 \mathrm{~h}$. (f) The amino acid sequence of $\mathrm{N}$ - and C-terminal truncated peptides for VnP-16. (g) Attachment of osteogenic cells induced by vitronectin, rVn-Fll, and peptides. (h) Attachment of NHEKs, NHOKs, NHDFs, NHOFs, PC-12 cells, MC3T3-E1 cells, CV-1 cells, and NIH/3T3 cells to VnP-16 $\left(9.1 \mu \mathrm{g} / \mathrm{cm}^{2}\right)$. The cells were allowed to adhere to VnP-16-treated plates for $1 \mathrm{~h}$ in serum-free medium. (i) The predicted structure of the VnP-16 dodecapeptide computed using the PSIPRED protein structure prediction server. The positions of the two $\beta$-strands (yellow arrows) on the coil (black line) are indicated. Conf, confidence of prediction; Pred, predicted secondary structure; AA, target sequence. Data in (b-e,g,h) represent the mean $\pm \mathrm{SD}(n=4) .{ }^{* *} P<0.01$

behavior (Figure 4k). Overall, these data support the concept that FAK phosphorylation at Tyr397 plays an essential role in $\mathrm{VnP}-16 / \beta 1$ integrin-mediated signaling and osteoblast differentiation.

VnP-16 promotes bone formation in vivo. To explore whether $\mathrm{VnP}-16$ promoted bone formation in vivo, we used an $8 \mathrm{~mm}$ critical-sized calvarial defect rat model. ${ }^{38}$ Microcomputed tomographic $(\mu \mathrm{CT})$ images of calvarial defects demonstrated that the vehicle- and SP-treated control groups showed limited new bone formation at the defect margins 2 weeks after surgery, whereas the $\mathrm{VnP}$-16-treated group showed distinctive bone healing (Figure 5a). The amount of regenerated bone in the $\mathrm{VnP}$-16-treated group was comparable to that in the recombinant human bone morphogenetic protein 2 (rhBMP-2)-treated group (Figure 5a). Quantitative bone morphometric analyses of the bone recovery rate (Figure 5b), bone volume/tissue volume ratio (BV/TV; Figure 5c), and calvarial thickness (Figure 5d), consistent with the greater amount of osteoid shown by Masson's trichrome staining (Figure 5e), confirmed that the VnP-16- treated group displayed a higher level of bone regeneration than the SP-treated groups. In the vehicle- and SP-treated control groups, the defects were mostly filled with loose fibrous connective tissues and degradation remnants of the absorbable collagen sponges used as scaffolds (Figure 5e). The number of osteoblasts per bone perimeter was significantly higher in the $\mathrm{VnP}$-16-treated group than the SPtreated group, and the number of osteoblasts in the $\mathrm{VnP}-16$ treated group was comparable to that in the rhBMP-2-treated group (Figure 5f). Furthermore, the expression levels of alkaline phosphatase and bone sialoprotein, early markers of osteoblast differentiation, were significantly higher in the VnP-16-treated group than the SP-treated control group (Figure $5 \mathrm{~g}$ ). These data demonstrate that $\mathrm{VnP}-16$ has a strong anabolic effect on bone formation by stimulating osteoblast differentiation and increasing osteoblast number.

VnP-16 restrains osteoclast differentiation by suppressing Janus N-terminal Kinase (JNK)-c-Fos-NFATc1 signaling. Next, we examined whether $\mathrm{VnP}-16$ could inhibit osteoclast differentiation by acting directly on osteoclast 

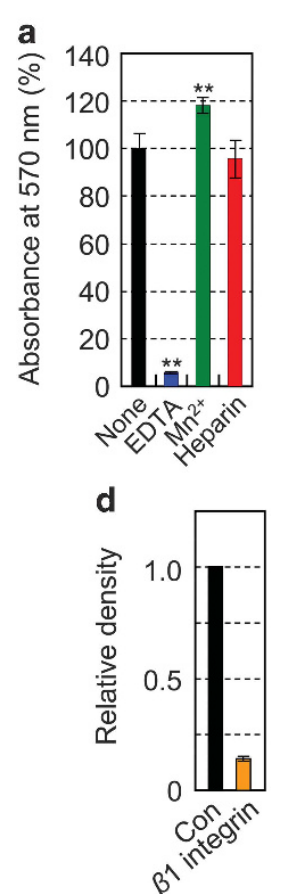
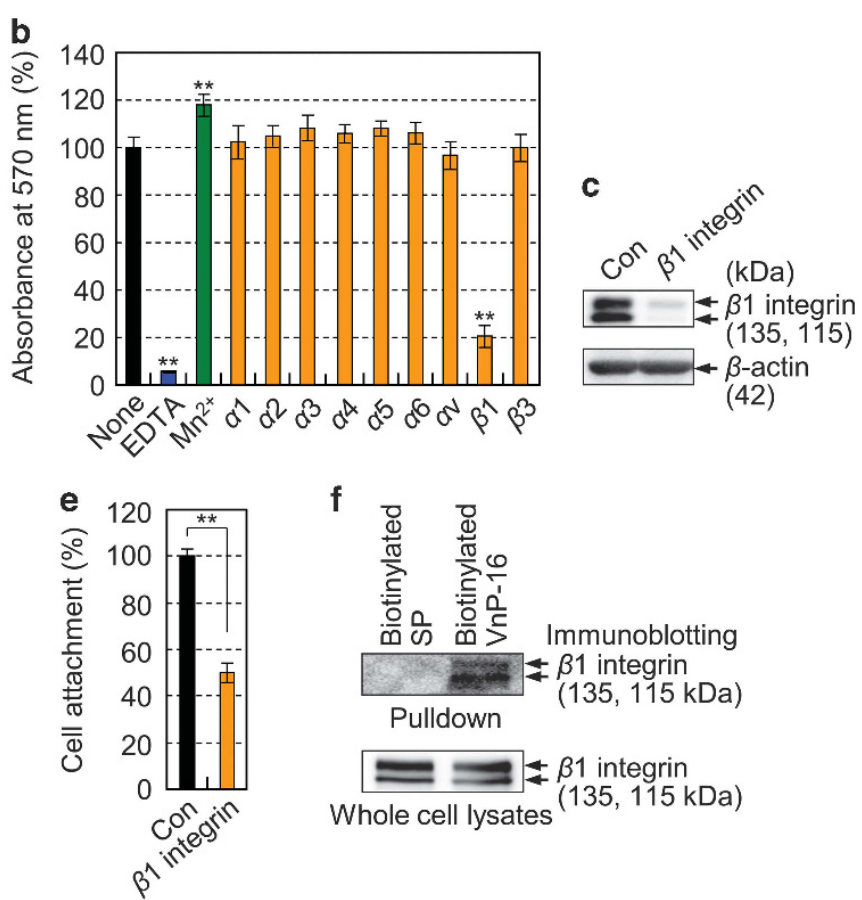

f

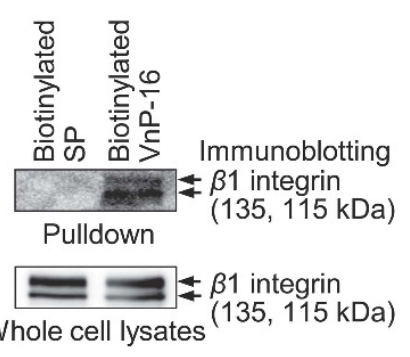

Figure $3 \mathrm{VnP}-16$ promotes osteogenic cell attachment through direct interaction with $\beta 1$ integrin. (a) Attachment of human osteogenic cells pretreated with EDTA (5 mM), $\mathrm{MnCl}_{2}(500 \mu \mathrm{M})$, or heparin $(100 \mu \mathrm{g} / \mathrm{ml})$ to $\mathrm{VnP}-16$. The cells were seeded onto plates that were precoated with VnP-16 $\left(9.1 \mu \mathrm{g} / \mathrm{cm}^{2}\right)$ for $1 \mathrm{~h}$. (b) The effects of various integrinblocking antibodies on cell attachment to VnP-16. (c-e) Immunoblotting (c) and densitometric analysis (d) of $\beta 1$ integrin, and cell attachment to VnP-16 (e) in osteogenic cells that were transfected with a control (Con) or $\beta 1$ integrin-specific siRNA (10 nM; $\beta 1$ integrin). (f) Streptavidin-bead pulldown assay with the biotinylated SP or biotinylated VnP-16 peptides from extracts of osteogenic cells that were cultured on biotinylated SP- or biotinylated VnP-16-coated dishes for 30 min. Data in $(\mathbf{a}, \mathbf{b}, \mathbf{e})(n=4)$, and (d) $(n=2)$ represent the mean $\pm \mathrm{SD} .{ }^{*} P<0.01$

precursor cells. M-CSF and RANKL induced the formation of numerous tartrate-resistant acid phosphatase (TRAP)-positive multinucleated osteoclasts from bone marrow-derived macrophages (BMMs; Figure 6a). VnP-16 inhibited M-CSF and RANKL-induced osteoclastogenesis almost completely, whereas vehicle and SP had no effect; notably, vitronectin also had no effect on osteoclastogenesis (Figures $6 a-c)$. The anti-osteoclastogenic effects of $\mathrm{VnP}-16$ were confirmed by its ability to suppress F-actin-mediated cytoskeletal organization in preosteoclasts (Figure 6d); however, VnP-16 had no such effect on mature osteoclasts (Supplementary Figure S4). To investigate whether $\mathrm{VnP}-16$ affects bone resorbing activity in vitro, BMMs were cultured for 6 days on Osteo Assay Surface plates that were coated with vehicle, vitronectin, SP, or $\mathrm{VnP}-16$, in the presence of M-CSF and RANKL. Numerous resorption pits caused by osteoclasts were generated in the vehicle- and SP-treated controls; however, VnP-16 inhibited the number and area of these pits significantly (Figures $6 \mathrm{e}$ and $\mathrm{f})$. In addition, when used at the concentration $(9.1 \mu \mathrm{g} /$ $\mathrm{cm}^{2}$ ) that blocked osteoclastogenesis, $\mathrm{VnP}-16$ did not affect the proliferation or viability of BMMs (Figure $6 \mathrm{~g}$ ), indicating that its inhibitory effect on osteoclastogenesis was not due to cytotoxicity or reduced cell proliferation.

To assess the molecular mechanisms underlying the inhibitory effects of $\mathrm{VnP}-16$ on M-CSF and RANKL-induced osteoclast differentiation, we examined the expression levels of c-Fos and NFATc1, which are crucial and fundamental transcription factors involved in osteoclast differentiation. ${ }^{20-22,25}$ Treatment of BMMs with VnP-16 suppressed the M-CSF and RANKL-induced expression of C-Fos and NFATc1 (Figures $6 \mathrm{~h}$ and i). To investigate the underlying mechanism, we examined the effects of $\mathrm{VnP}-16$ on the activation of MAPKs, the upstream regulators of c-Fos and NFATc1. These RANKL downstream signaling events have been implicated in the expression of c-Fos and NFATc1 and osteoclast differentiation. ${ }^{39,40} \mathrm{VnP}-16$ did not affect basal JNK levels but it did inhibit RANKL-stimulated JNK phosphorylation (Figures 6j and k). By contrast, VnP-16 did not affect RANKLinduced phosphorylation of extracellular signal-regulated kinase or p38 (Figures 6j and k). Thus, suppression of JNK phosphorylation by $\mathrm{VnP}-16$ resulted in a decrease of c-Fos and NFATc1 expression, which in turn led to the negative regulation of osteoclast differentiation.

VnP-16 suppresses cytoskeletal organizers in osteoclasts by disturbing $a v \beta 3$ integrin signaling. Because the average size of the M-CSF and RANKL-induced osteoclasts was reduced by $\mathrm{VnP}-16$ (Figure 6c), we studied the effects of $\mathrm{VnP}-16$ on the levels of $\alpha \mathrm{v} \beta 3$ integrin signalingrelated molecules. PYK2 and $\mathrm{c}-\mathrm{Src}$ are responsible for organizing the osteoclast cytoskeleton. ${ }^{30,41,42}$ Binding of a ligand to $a v \beta 3$ integrin activates $\mathrm{c}$-Src by phosphorylating Tyr416, thereby leading to organization of the actin cytoskeleton, ${ }^{43}$ and engagement of $\mathrm{c}-\mathrm{Src}$ and PYK2 with av $\beta 3$ integrin is related to the resorptive function of mature osteoclasts. $^{30,41}$ Therefore, we suspected that $a v \beta 3$ integrin 
a

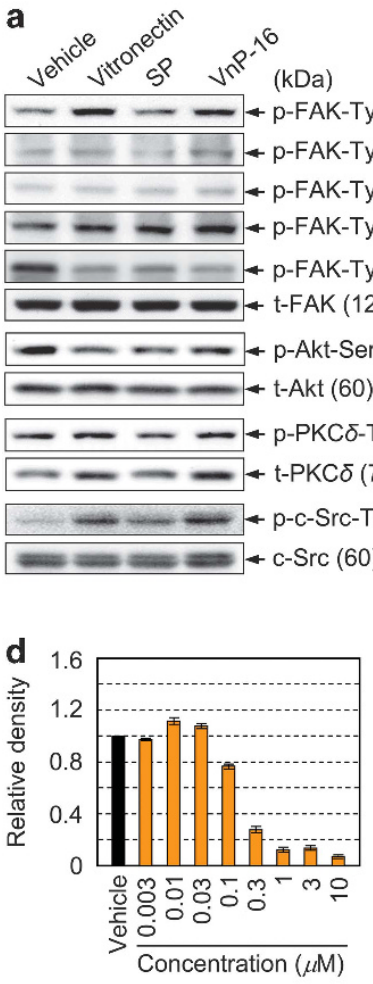

g
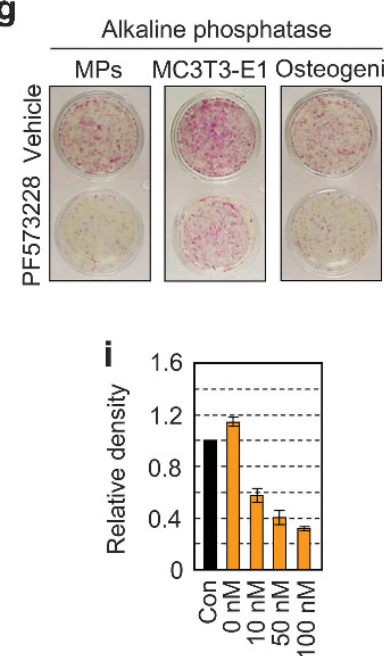

7 (125)

$07(125)$

6 (125)

$$
73(60)
$$

Thr505 (77)

$416(60)$
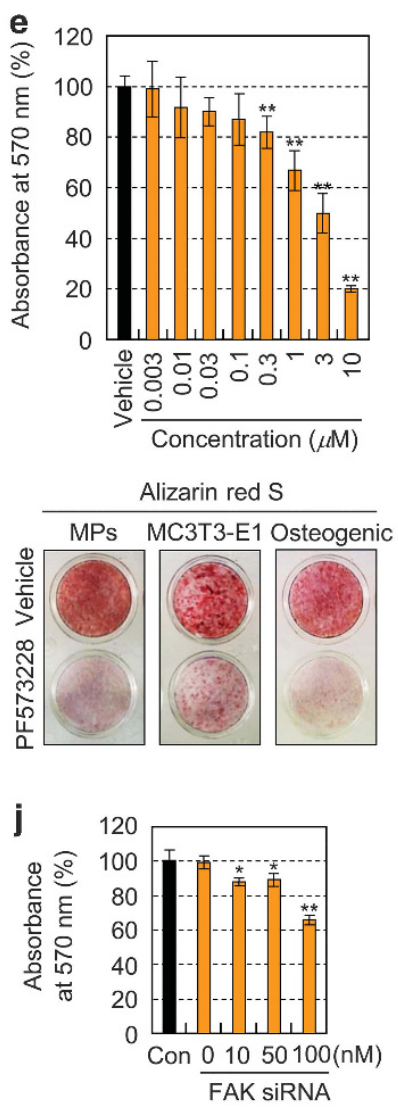

C
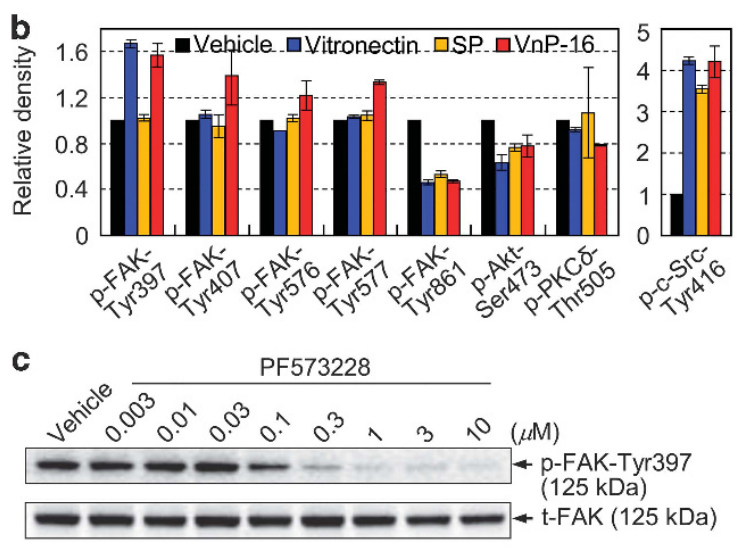

f $\frac{\text { Alkaline phosphatase }}{\text { MPs MC3T3-E1 Osteogenic }}$

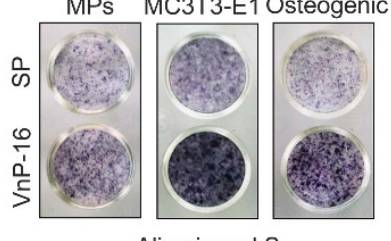

Alizarin red $\mathrm{S}$

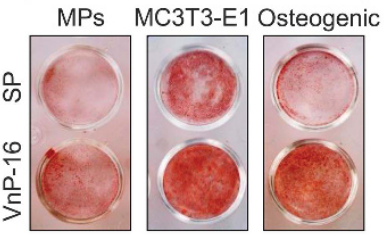

h

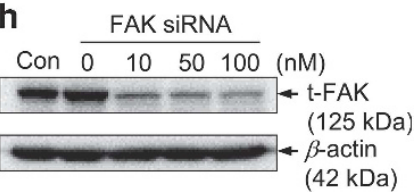

$\mathbf{k}$

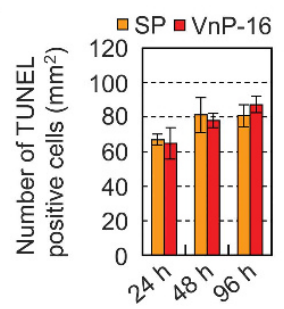

Figure $4 \quad \mathrm{VnP}-16$ promotes osteogenic differentiation through $\beta 1$ integrin/FAK signaling. (a,b) Immunoblotting (a) and densitometric analyses (b) of phospho-FAK, phosphoAkt Ser473, phospho-PKC $\delta$ Thr505, and phospho-c-Src Tyr416 in osteogenic cells that were cultured for $3 \mathrm{~h}$ on plates coated with vitronectin $\left(0.23 \mu \mathrm{g} / \mathrm{cm}^{2}\right), \mathrm{SP}$, or $\mathrm{VnP}-16$ $\left(9.1 \mu \mathrm{g} / \mathrm{cm}^{2}\right)$. (c,d) Immunoblotting (c) and densitometric analyses (d) of total FAK (t-FAK) and phospho-FAK Tyr397 in osteogenic cells that were pretreated with PF-573228 for $1 \mathrm{~h}$. (e) Attachment of cells that were treated with PF-573228 for $1 \mathrm{~h}$ in serum-free medium to plates precoated with VnP-16 $\left(9.1 \mu \mathrm{g} / \mathrm{cm}^{2}\right)$. (f) The effects of VnP-16 on alkaline phosphatase activity and calcium deposition in SKP-derived mesenchymal precursors (MPs), mouse calvarial osteoblast precursors (MC3T3-E1), and human osteogenic cells (Osteogenic). The cells were cultured in osteogenic differentiation medium containing VnP-16 or SP $(50 \mu \mathrm{g} / 0.5 \mathrm{ml})$ for 2 weeks. (g) The effects of PF-573228 on alkaline phosphatase activity and calcium deposition in SKP-derived mesenchymal precursors, MC3T3-E1, and human osteogenic cells. The cells were cultured on VnP-16-treated $\left(9.1 \mu \mathrm{g} / \mathrm{cm}^{2}\right)$ plates in osteogenic differentiation medium with or without $1 \mu \mathrm{M} \mathrm{PF}-573228$ for 2 weeks. (h-j) Immunoblotting (h) and densitometric analyses (i) of t-FAK, and dosedependent attachment (j) of control or FAK-specific siRNA-treated (100 nM) osteogenic cells to VnP-16. (k) Determination of apoptotic cells in osteogenic cells that were cultured for 24,48 , and $96 \mathrm{~h}$ on plates coated with SP or VnP-16 $\left(9.1 \mu \mathrm{g} / \mathrm{cm}^{2}\right)$ by TUNEL assay. Data in $(\mathbf{b}, \mathbf{d}$ and $\mathbf{i})(n=3)$, and $(\mathbf{e}, \mathbf{j}$ and $\mathbf{k})(n=4)$ represent the mean \pm SD. ${ }^{*} P<0.05$ or ${ }^{* *} P<0.01$ compared to vehicle or control siRNA

signaling might be involved in the inhibition of M-CSF- and RANKL-induced resorptive function by VnP-16. In BMMs, VnP-16 disturbed the M-CSF- and RANKL-induced phosphorylation of C-Src at Tyr416 and PYK2 at Tyr402
(Figures $7 \mathrm{a}$ and $\mathrm{b}$ ). Similarly, $\mathrm{VnP}-16$ inhibited and suppressed the phosphorylation of these proteins in preosteoclasts (Figures 7c and d) and mature osteoclasts (Figures 7e and f), respectively. Furthermore, $\mathrm{VnP}-16$ altered the level of 
GTP-bound Rac1, the final molecular effector of $a v \beta 3$ integrin signaling, during M-CSF- and RANKL-induced osteoclastogenesis in BMMs (Figures $7 g$ and h). Notably, unlike SP, VnP-16 inhibited GTP-bound Rac1 expression in preosteoclasts (Figures $7 \mathrm{i}$ and $\mathrm{j}$ ). Taken together, these data demonstrate that $\mathrm{VnP}-16$ suppresses $a \mathrm{v} \beta 3$ integrin signaling-related molecules during the M-CSF- and RANKLinduced bone resorption process, thereby inhibiting cytoskeletal organization in osteoclasts.

VnP-16 inhibits bone resorbing activity of pre-existing osteoclasts and prevents interleukin-1a (IL-1a)-mediated bone loss in vivo. To assess the resorptive activity of pre-existing osteoclasts in vitro, mature osteoclasts were cultured on Osteo Assay Surface plates that were coated with vehicle, vitronectin, SP, or VnP-16, in the presence of M-CSF and RANKL. After 12 and $24 \mathrm{~h}$, numerous resorption pits caused by osteoclasts were generated in the vehicle- and SP-treated controls; however, $\mathrm{VnP}-16$ inhibited the area of these pits significantly (Figures $8 \mathrm{a}$ and b; Supplementary Figures S5a and b). VnP-16, however, had no effect on osteoclast survival (Supplementary Figure S5c).

To ascertain the biological potency of $\mathrm{VnP}-16$ on bone resorption in vivo, we investigated the effects of $\mathrm{VnP}-16$ on IL-1 $a$-induced bone destruction in mice. $\mu \mathrm{CT}$ images and TRAP staining of whole calvariae revealed that IL-1a

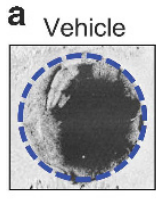

e
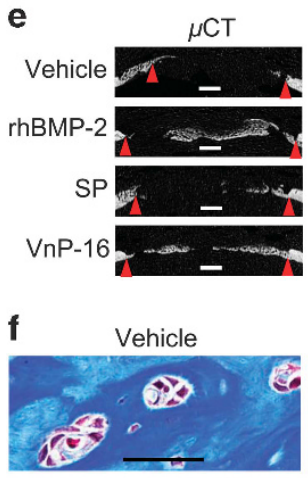

SP

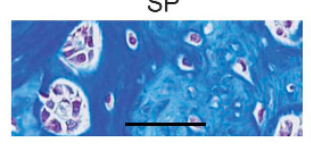

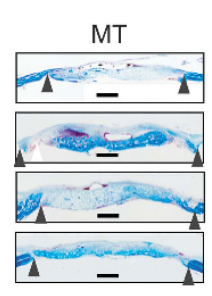

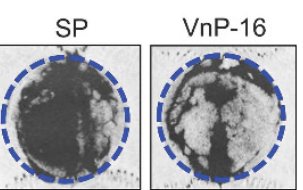

rhBMP-2

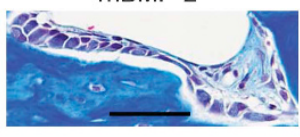

$\mathrm{VnP}-16$

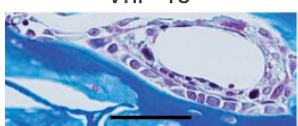

b
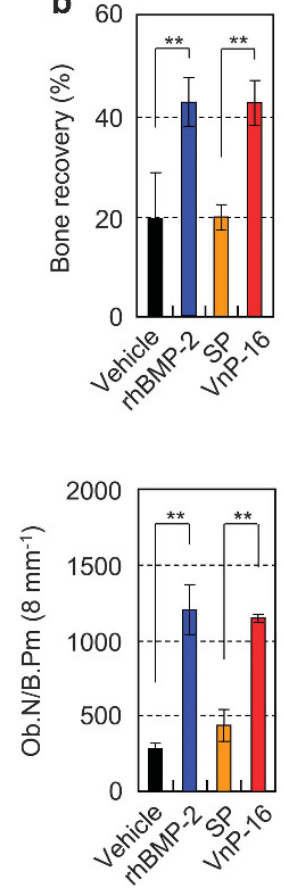
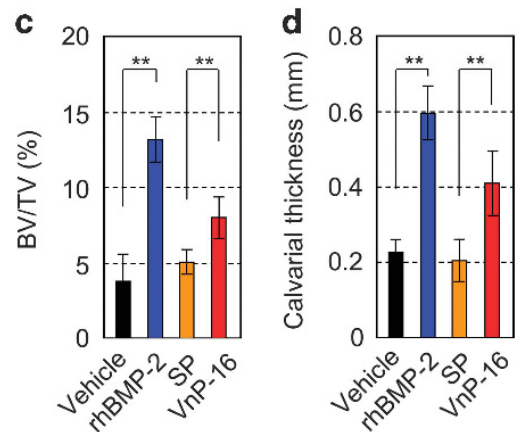

g

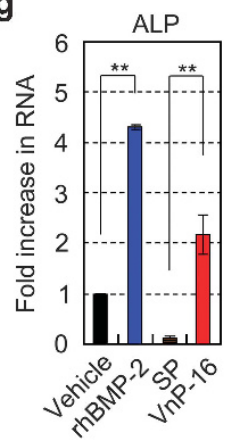

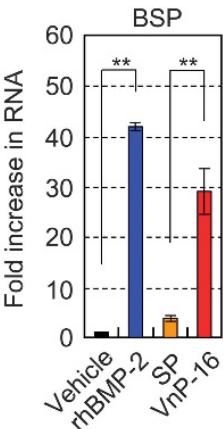

Figure 5 The effects of $\mathrm{VnP}-16$ on bone regeneration in vivo. (a) $\mu \mathrm{CT}$ images of the bone defects in each group. Critical-sized rat calvarial defects were implanted with absorbable collagen sponges treated with vehicle (DMSO), rhBMP-2 $(2 \mu \mathrm{g} / \mathrm{scaffold}), \mathrm{SP}(1 \mathrm{mg} / \mathrm{scaffold})$, or VnP-16 (1 mg/scaffold). (b-d) Quantitative bone morphometric analyses of the bone recovery rate (b), BV/TV (c), and calvarial thickness (d) in the region of the defects. (e) $\mu \mathrm{CT}$ images of the bone defects and Masson's trichrome staining (MT) of rat calvarial sections 2 weeks after transplantation. The triangles indicate the wound edges. For histomorphometric analysis, the specimens were decalcified with $12 \%$ EDTA for 4 weeks and embedded in paraffin. The paraffin-embedded samples were sectioned at a thickness of $4 \mu \mathrm{m}$ and then stained with Masson's trichrome. Scale bars, $1 \mathrm{~mm}$. (f) The number of osteoblasts per bone perimeter from rat calvarial sections 2 weeks after transplantation. Ob.N, osteoblast number; B.Pm, bone perimeter. (Scale bars, $50 \mu \mathrm{m}$.) (g) qPCR analysis of the expression levels of osteogenic markers in each group. ALP, alkaline phosphatase; BSP, bone sialoprotein. Data in (b-d, $\mathbf{f}$ and $\mathbf{g})$ represent the mean $\pm \operatorname{SD}\left(n=5\right.$ per group). ${ }^{* *} P<0.01$

Figure 6 The effects of VnP-16 on M-CSF- and RANKL-induced osteoclast formation, F-actin-mediated cytoskeletal organization, resorptive activity, and the expression levels of osteoclastogenesis-related genes. (a-d) BMMs were cultured for 6 days on plates that were precoated with vehicle (DMSO), vitronectin $\left(0.23 \mu \mathrm{g} / \mathrm{cm}^{2}\right), \mathrm{SP}\left(9.1 \mu \mathrm{g} / \mathrm{cm}^{2}\right)$, or VnP-16 $\left(9.1 \mu \mathrm{g} / \mathrm{cm}^{2}\right)$, in the presence of $30 \mathrm{ng} / \mathrm{ml} \mathrm{M-CSF}$ and $100 \mathrm{ng} / \mathrm{ml}$ RANKL. The induced cells were stained for TRAP (a) and immunostained with DAPI (blue) and rhodamine-phalloidin (F-actin, red) (d). TRAP-positive multinucleated cells containing three or more nuclei were counted as osteoclasts (b). The sizes of the osteoclasts were obtained by measuring the diameters of multinucleated TRAP-positive cells on $\times 40$ photomicrographs (c). Scale bars, $200 \mu \mathrm{m}$. (e and f) The effects of VnP-16 on the bone resorbing activity of osteoclasts. BMMs were cultured for 6 days on Osteo Assay Surface plates that were coated with vehicle (DMSO), vitronectin $\left(0.23 \mu \mathrm{g} / \mathrm{cm}^{2}\right)$, or synthetic peptide $\left(9.1 \mu \mathrm{g} / \mathrm{cm}^{2}\right)$, in the presence of $30 \mathrm{ng} / \mathrm{ml} \mathrm{M-CSF}$ and $100 \mathrm{ng} / \mathrm{ml} \mathrm{RANKL}$. The cells were removed and the resorbed pits were photographed (e). The blue arrows indicate the resorption pits formed by osteoclasts. Bone resorption was assessed by pit area measurements (f). Scale bars, $200 \mu \mathrm{m}$. (g) The effect of the concentration of VnP-16 (9.1 $\mu \mathrm{g} /$ $\mathrm{cm}^{2}$ ) that blocked osteoclast formation on the proliferation and viability of BMMs. (h and i) Immunoblotting (h) and densitometric analyses (i) of the osteoclastogenesis-related proteins in BMMs that were cultured for 1-3 days on plates precoated with SP or VnP-16 $\left(9.1 \mu \mathrm{g} / \mathrm{cm}^{2}\right)$, in the presence of $30 \mathrm{ng} / \mathrm{ml}$ M-CSF and $100 \mathrm{ng} / \mathrm{ml}$ RANKL. CREB, cAMPresponse element-binding protein; ATF-1, activating transcription factor 1. (j,k) Immunoblotting (j) and densitometric analyses (k) of MAPKs in BMMs that were cultured for 3 days on plates precoated with SP or VnP-16 $\left(9.1 \mu \mathrm{g} / \mathrm{cm}^{2}\right)$, in the presence of $30 \mathrm{ng} / \mathrm{ml} \mathrm{M-CSF}$ and $100 \mathrm{ng} / \mathrm{ml} \mathrm{RANKL}$, serum-starved for $3 \mathrm{~h}$, and stimulated with M-CSF $(30 \mathrm{ng} / \mathrm{ml})$ and RANKL $(100 \mathrm{ng} / \mathrm{ml})$ for the indicated times. ERK, extracellular signal-regulated kinase. Data in $(\mathbf{b}, \mathbf{c}, \mathbf{f}$ and $\mathbf{g})(n=4)$, and $(\mathbf{i}$ and $\mathbf{k})(n=3)$ represent the mean \pm SD. ${ }^{*} P<0.01$ 
treatment resulted in severe bone destruction (Figure 8c). Compared with that in the IL-1a-plus SP-treated group, bone destruction was significantly lower in the $\mathrm{IL}-1 a$ - plus VnP-16-treated group (Figure 8c). Furthermore, IL-1a decreased the mineral content and BV/TV of calvarial bones, and these effects were significantly less pronounced in the
VnP-16-treated group than the SP-treated group (Figures 8d and e). Histological and histomorphometric analyses of calvarial bones showed that IL-1 $a$ increased the number and its surface area of TRAP-positive osteoclasts; however, $\mathrm{VnP}-16$ significantly reduced these IL-1a-induced parameters (Figures 8f-h).
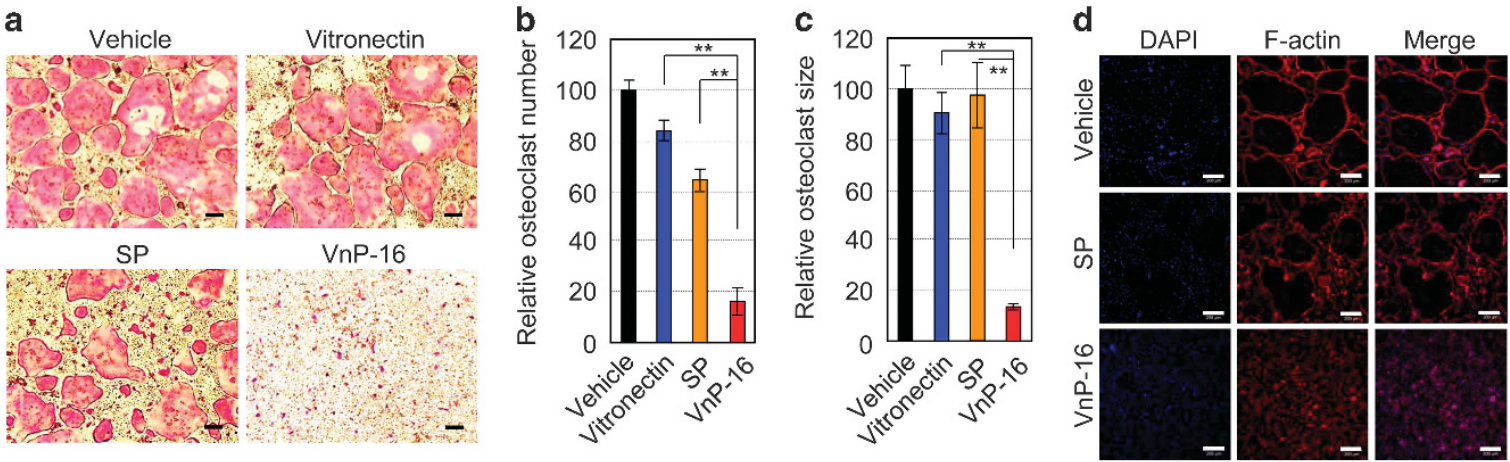

e

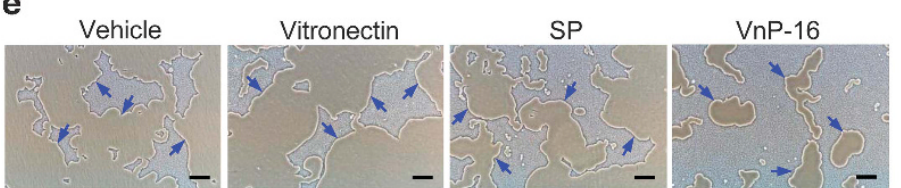

h
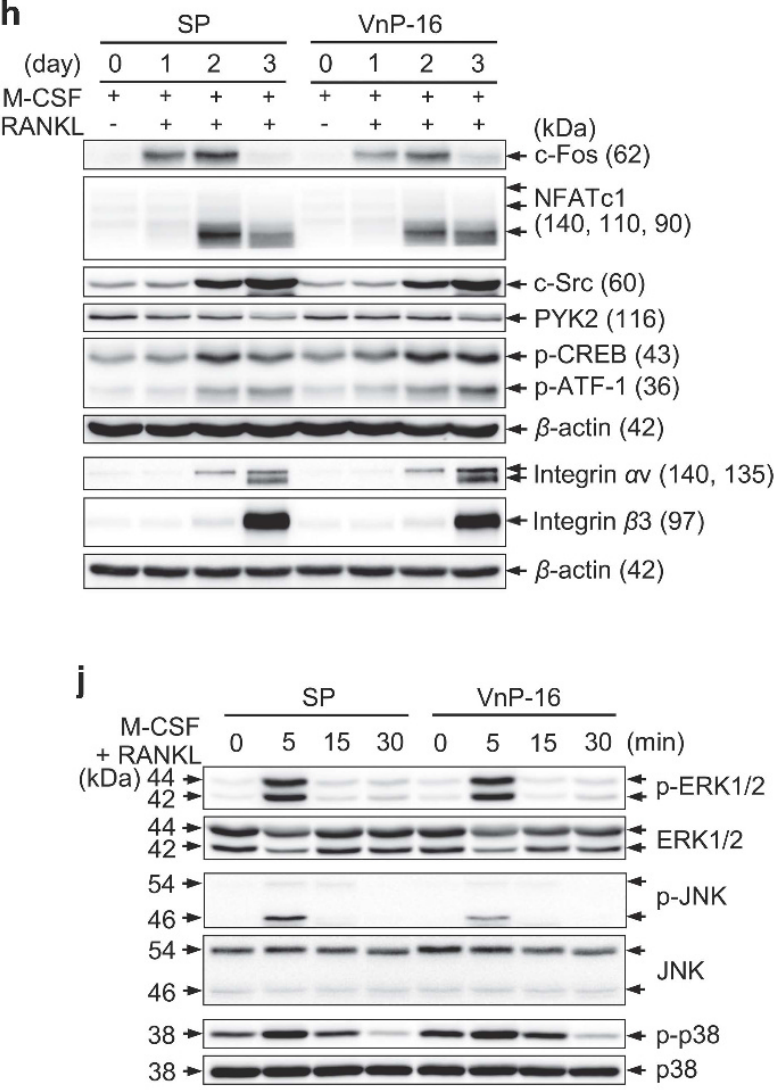

f
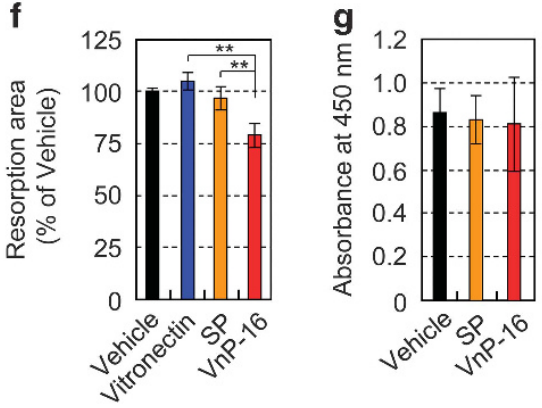

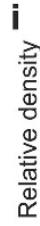
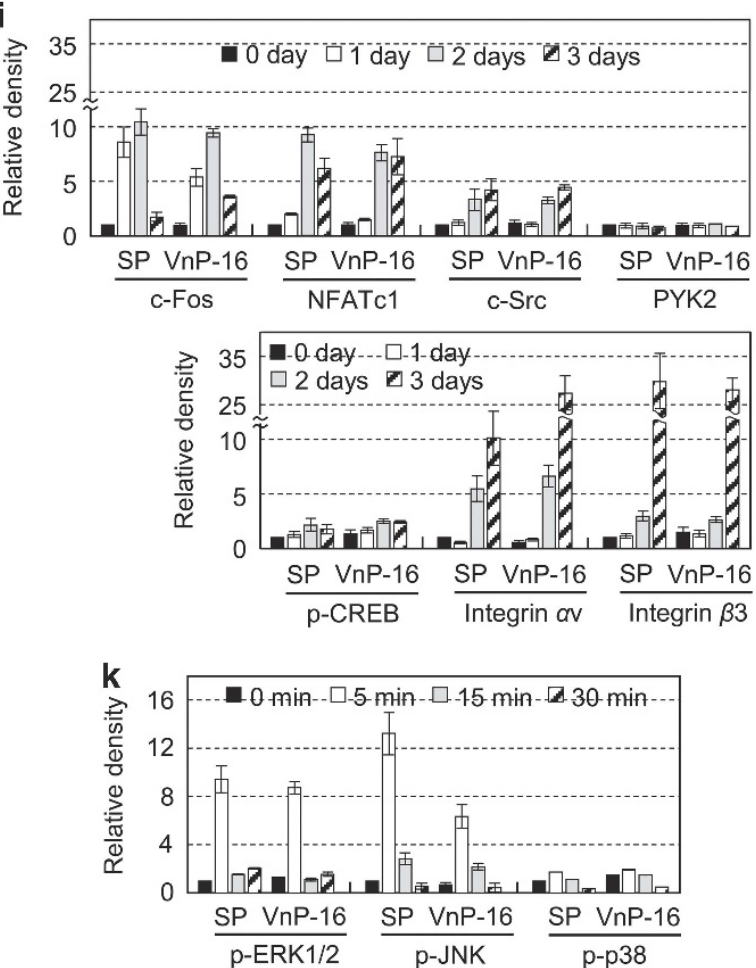
VnP-16 substantially reverses estrogen deficiencyinduced bone loss. To explore whether $\mathrm{VnP}-16$ restored bone loss in vivo, we examined whether it could reverse the established bone loss induced by ovariectomy (OVX) in mice. We found that OVX mice displayed noticeable trabecular bone loss (Supplementary Figure S6a). Quantitatively, bone mineral density (BMD), BV/TV, trabecular number, and osteoblast number were significantly reduced (Supplementary Figures S6b-e), but the number and its surface area of TRAP-positive osteoclasts were significantly increased (Supplementary Figures S6f and g) in mice at 12 weeks following OVX, demonstrating that OVX induces severe bone loss in the femur. Next, to evaluate the therapeutic value of $\mathrm{VnP}-16$, we administered synthetic peptides, rhBMP-2, or vehicle to OVX mice once via intrafemoral injection, waited for 1 week, and then performed $\mu \mathrm{CT}$ analysis and histological staining of femurs from these mice. VnP-16-treated OVX mice showed marked bone restoration (Figure 9a) and significantly higher degrees of BMD (Figure 9b), BV/TV (Figure 9c), and trabecular number (Figure 9d) than vehicle- or SP-treated OVX mice. Similarly, Masson's trichrome staining confirmed that $\mathrm{VnP}-16$ enhanced osteoid formation in vivo (Figure 9e). In this regard, rhBMP-2 also had a strong bone anabolic effect in OVX mice; surprisingly, the bone-restorative effect of $\mathrm{VnP}-16$ in OVX mice was similar to that of rhBMP-2 (Figures 9a-e), which is known as the most effective osteoinductive protein. Quantitatively, VnP-16 and rhBMP-2 restored $42 \%$ and $29 \%$ of the BMD, respectively, compared with vehicle- or SPtreated OVX mice (Figure 9b).

To further evaluate whether the marked bone restoration induced by $\mathrm{VnP}-16$ treatment is primarily due to either osteoblastogenesis or inhibition of osteoclastogenesis, we examined the ability of $\mathrm{VnP}-16$ to generate osteoblasts and osteoclasts from femoral trabecular bone in OVX mice. Hematoxylin and eosin (H\&E) staining and histomorphometric analysis revealed that the osteoblast number was significantly higher and the osteoblast surface was significantly larger in VnP-16-treated OVX mice than in vehicle- or SP-treated OVX mice (Figures $9 f-h)$. By contrast, the osteoclast number was significantly lower and the osteoclast surface was significantly smaller in $\mathrm{VnP}-16$ treated OVX mice than in vehicle- or SP-treated OVX mice (Figures 9i-k). Quantitatively, the osteoblast number was 2.4fold higher but the osteoclast number was 0.5 -fold lower in VnP-16-treated OVX mice than in vehicle-treated OVX mice (Figures $9 \mathrm{~g}$ and $\mathrm{j}$ ).

\section{Discussion}

In this study, we performed a series of in vitro and in vivo studies to demonstrate that the vitronectin-derived VnP-16 peptide could be an attractive therapeutic agent for the treatment of osteoporosis by blocking bone catabolism and promoting bone anabolism (Figure 9l). Using three different, but complementary, animal models, we demonstrated that $\mathrm{VnP}-16$ could enhance bone regeneration in rat calvarial critical-sized bone defects by promoting osteoblast differentiation and increasing osteoblast number, and alleviate IL-1ainduced bone resorption by restraining osteoclast differentiation and function. Moreover, $\mathrm{VnP}-16$ could reverse OVX-induced bone loss by both inhibiting bone resorption and promoting bone formation. In vivo, both osteoblastogenesis and inhibition of osteoclastogenesis actively occurred to an almost equal extent in VnP-16-treated OVX mice, although the level of the former was slightly higher than that of the latter. In addition, $\mathrm{VnP}-16$ did not promote the attachment of primary human keratinocytes, which suggests that it effectively enhances the bone regeneration capacity without causing epithelial migration. Notably, periodontal regeneration can only be achieved when epithelial migration on the treated root surface is prevented. ${ }^{44,45}$

To further elucidate the molecular mechanism by which VnP-16 inhibited bone resorption and promoted bone formation, we examined each key step of osteoblast and osteoclast differentiation and how they were affected by this peptide in vitro. $\mathrm{VnP}-16$ inhibited osteoclastogenesis and bone resorption by suppressing JNK-c-Fos-NFATc1-induced osteoclast differentiation and $a v \beta 3$ integrin-c-Src-PYK2-mediated resorptive function, while it promoted bone formation by enhancing osteoblast differentiation via direct interaction with $\beta 1$ integrin. Therefore, $\mathrm{VnP}-16$ holds promise as a potential therapeutic agent for osteoporosis. Peptides can elicit different responses depending on their receptors and the cellular context. $\mathrm{VnP}-16$, which is predicted to have two $\beta$-strands, promoted osteogenic cell functions through $\beta 1$ integrin by inducing phosphorylation of FAK at Tyr-397 and -577, and c-Src at Tyr416; in fact, FAK activation by $\mathrm{VnP}-16$ was crucial for osteoblast differentiation. Consistent with this, the rapid phosphorylation of FAK at Tyr397 is a hallmark of FAK activation upon integrin-mediated cell attachment and spreading. ${ }^{46}$

NFATc1 induction is dependent on both the TRAF6-NF- $k B$ and c-Fos pathways, which are activated by RANKL and $\mathrm{Ca}^{2+}$ signaling. ${ }^{22,25}$ Here we found that $\mathrm{VnP}-16$ restrained JNK phosphorylation, leading to the suppression of c-Fos and NFATc1, downstream regulators of JNK, during osteoclastogenesis. To explain the $\mathrm{VnP}$-16-mediated osteoclast function, we also examined the effect of this peptide on $a v \beta 3$ integrin signaling. The involvement of $\mathrm{c}-\mathrm{Src}$ in osteoclast function has been validated by studying osteopetrotic Src-deficient mice. ${ }^{47}$ The interaction of PYK2 with $a \mathrm{v} \beta 3$ integrin leads to c-Srcdependent phosphorylation at Tyr402 and subsequent activation of PYK2. ${ }^{30,41}$ The data presented here show that $\mathrm{VnP}-16$ disturbed or inhibited M-CSF- and RANKL-induced activation of cytoskeletal organizers during osteoclastogenesis. The anti-osteoclastogenic activity of $\mathrm{VnP}-16$ was confirmed by its ability to suppress F-actin-mediated cytoskeletal organization. Moreover, $\mathrm{VnP}-16$ decreased the bone resorbing activity of pre-existing mature osteoclasts without changing their survival rate. Thus, these data reveal the precise mechanism by which $\mathrm{VnP}-16$ affects osteoclast differentiation and function, including the resorptive activity of mature osteoclasts, thereby inhibiting bone resorption.

Most drugs currently used to treat osteoporosis are inhibitors of bone resorption; however, they cannot reverse the substantial bone loss that has already occurred by the time of diagnosis. ${ }^{48}$ Therefore, a better treatment strategy for osteoporosis would not only block bone resorption, but also promote bone formation while controlling local 
a

C

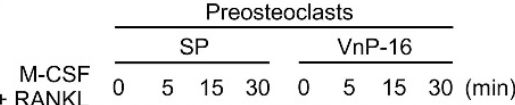

(kDa) $60 \rightarrow \equiv \equiv \equiv \equiv \equiv$

$60 \div-\square-C-\mathrm{CrC}$

$116 \rightarrow--\square-\mathrm{p}-\mathrm{PYK} 2-\mathrm{Tyr} 402$

$116 \rightarrow \square-\square+\mathrm{PYK} 2$

$43 \rightarrow-\infty-\infty-\mathrm{p}-\mathrm{CREB}$

$36 \rightarrow---\div-\cdots+$ p-ATF-1

$42 \rightarrow \longrightarrow+\beta$-actin

e

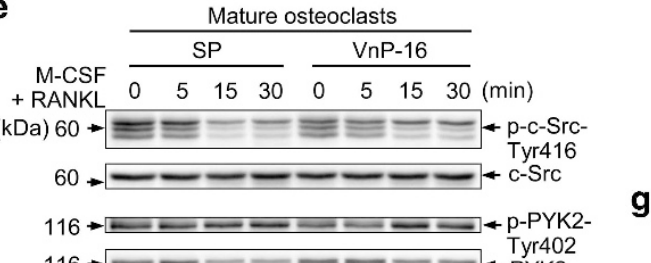

$116 \rightarrow \square$ Tyr402

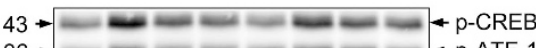

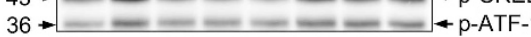

$42 \rightarrow$

BMMs

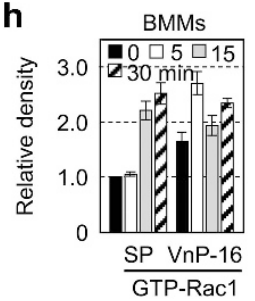

g

i b

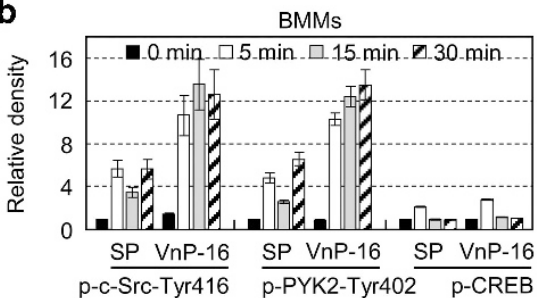

d

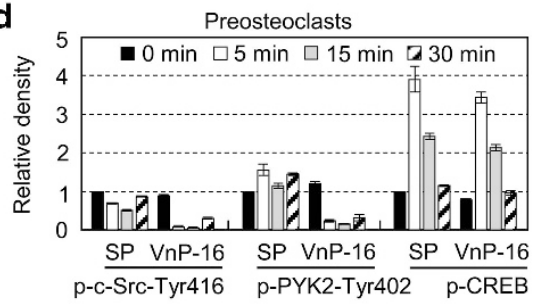

f
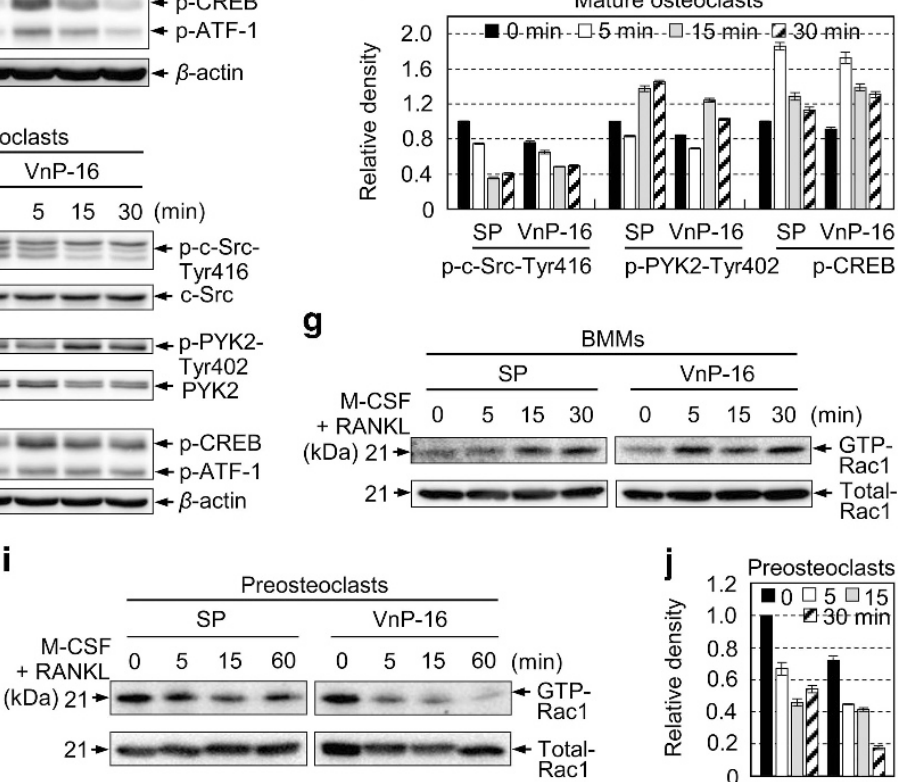

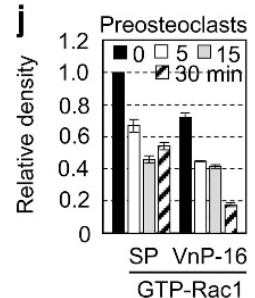

Figure 7 The effects of VnP-16 on M-CSF- and RANKL-induced activation of cytoskeletal organizers during osteoclastogenesis. (a-f) Immunoblotting (a,c,e) and densitometric analyses (b, d and f) of c-Src, PYK2, and CREB in BMMs (a and $\mathbf{b})$, preosteoclasts (c and $\mathbf{d})$ ), and mature osteoclasts (e and f). The cells were cultured for 1 day (a and $\mathbf{e}$ ) or 3 days (c) on plates that were precoated with SP or VnP-16 $\left(9.1 \mu \mathrm{g} / \mathrm{cm}^{2}\right)$, in the presence of $30 \mathrm{ng} / \mathrm{ml} \mathrm{M}-\mathrm{CSF}$ and $100 \mathrm{ng} / \mathrm{ml}$ RANKL, serum-starved for $3 \mathrm{~h}$, and then stimulated with M-CSF $(30 \mathrm{ng} / \mathrm{ml})$ and RANKL $(100 \mathrm{ng} / \mathrm{ml})$ for the indicated times. ( $\mathbf{g}-\mathbf{j})$ Immunoblotting $(\mathbf{g}$ and $\mathbf{i})$ and densitometric analyses (h and $\mathbf{j})$ of active (GTP-Rac1) and total Rac1 levels in BMMs ( $\mathbf{g}$ and $\mathbf{h}$ ) and preosteoclasts (i and $\mathbf{j})$. The assay conditions were the same as those described for $(\mathbf{a}$ and $\mathbf{c}$ ). The cells were lysed and incubated with PAK1 PBD Agarose beads for $1 \mathrm{~h}$ at $4{ }^{\circ} \mathrm{C}$. Active Rac1 proteins were detected by immunoblotting using an anti-Rac1 antibody. Data in (b, $d, f, h$ and $\left.\mathbf{j}\right)$ represent the mean \pm SD $(n=3)$

inflammation. ${ }^{48,49}$ Our results suggest that the simultaneous inhibition of bone resorption and promotion of bone formation by $\mathrm{VnP}-16$ make it a better, and perhaps safer, therapeutic agent for the treatment of osteoporosis.

\section{Materials and Methods}

More in Supplementary Materials and Methods.

Peptides and reagents. All peptides were synthesized on a Pioneer Peptide Synthesizer (Applied Biosystems, Foster City, CA, USA) using the 9-fluorenylmethoxycarbonyl-based solid-phase method with a C-terminal amide. The peptides were purified and characterized by Peptron (Daejeon, Korea). All the peptides used in the study had a purity greater than $95 \%$, as determined using highperformance liquid chromatography. Human plasma vitronectin was purchased from Millipore (Bedford, MA, USA)

Preparation of human primary cells, osteogenic cells, and BMMs. NHEKs, NHOKs, NHDFs, and NHOFs were prepared and maintained as described previously. ${ }^{50,51}$ To prepare human osteogenic cells, multipotent SKPs were isolated from human foreskins of 1-3-year-old patients undergoing surgery, as described previously. ${ }^{52,53}$ For the serial sphere formation assay, subculturing was performed once a week for 3 weeks after dissociation of the spheres with Accutase 
a

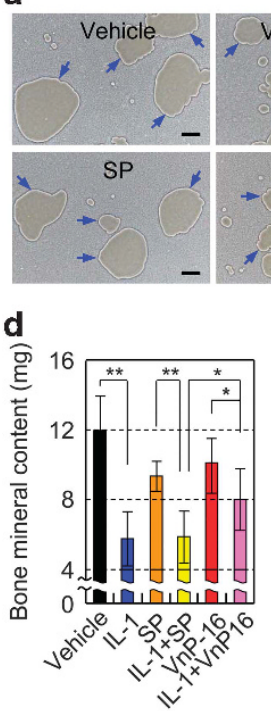

g

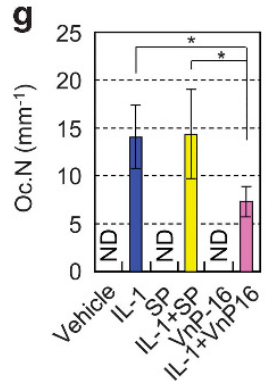

b

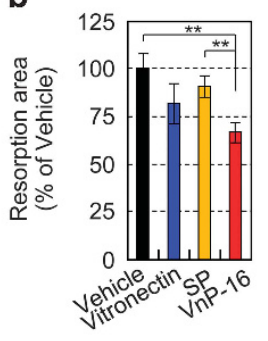

c

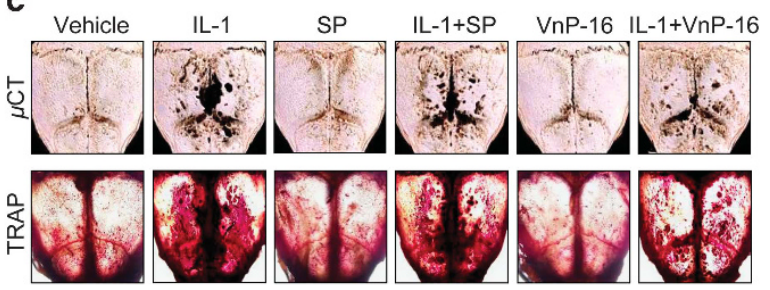

e
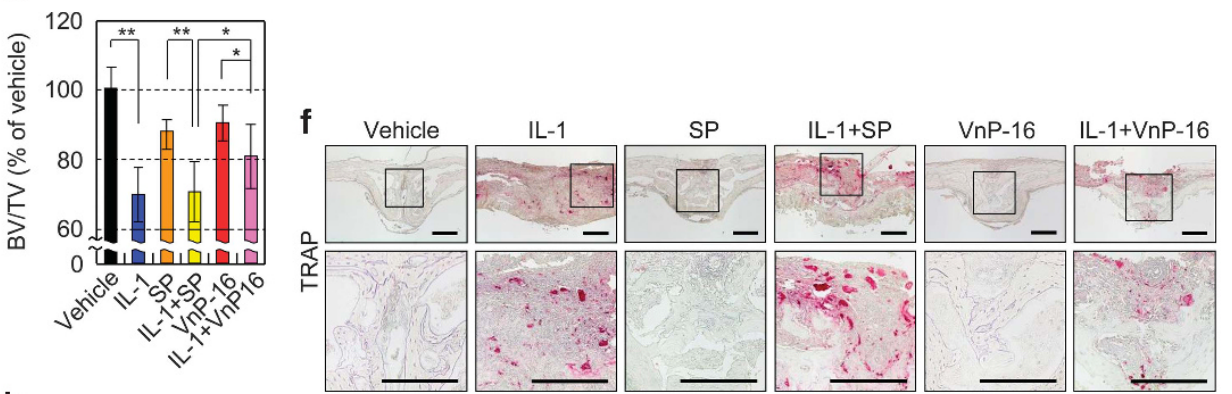

h
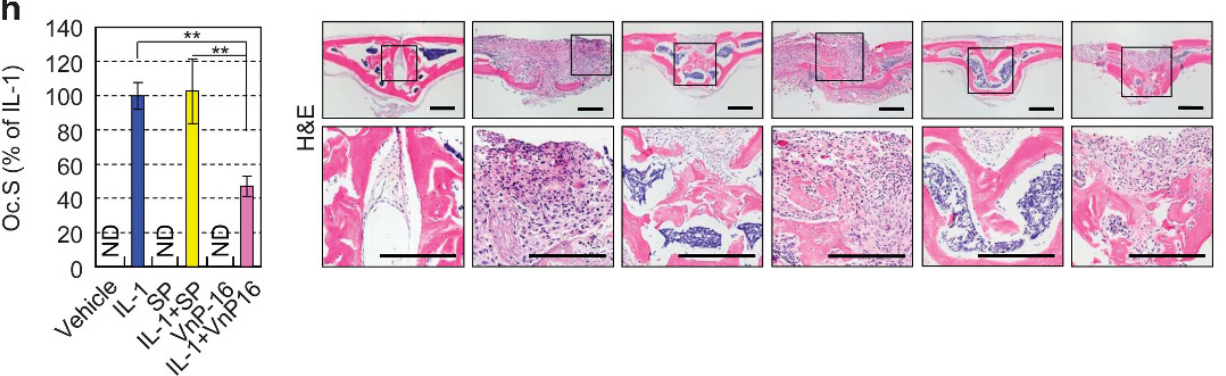

Figure 8 The effects of VnP-16 on bone resorbing activity in vitro and IL-1-induced bone destruction in vivo. (a and $\mathbf{b})$ The effects of $\mathrm{VnP}-16$ on the bone resorbing activity of mature osteoclasts. The assay conditions were the same as in Figure 6e, except that mature osteoclasts cultured for $12 \mathrm{~h}$ on Osteo Assay Surface plates were used (a). Bone resorption was assessed by pit area measurements (b). Scale bars, $200 \mu \mathrm{m}$. (c-e) The effects of VnP-16 on IL-1-induced bone destruction in vivo. A collagen sponge treated with vehicle (DMSO), IL-1 $(2 \mu \mathrm{g})$, synthetic peptides (125 $\mu \mathrm{g})$, or synthetic peptides $(125 \mu \mathrm{g})$ plus IL-1 $(2 \mu \mathrm{g})$ was implanted over the calvarial bone of 5 -week-old ICR mice. TRAP staining and $\mu \mathrm{CT}$ imaging of whole calvariae were performed (c); the black spots indicate eroded surfaces. Bone mineral content (d) and BV/TV (e) were measured by quantitative bone morphometric analysis. ( $f-h)$ Histological sections of calvarial bones were stained with H\&E (f, bottom) and histochemically for TRAP (f, top). The osteoclast number $(\mathbf{g})$ and surface area $(\mathbf{h})$ were determined by histomorphometric analysis. Oc.N, osteoclast number; Oc.S, osteoclast surface. Scale bars, $200 \mu \mathrm{m}$. Data in (b, $\mathbf{d}, \mathbf{e}, \mathbf{g}$ and h) represent the mean $\pm \mathrm{SD}\left(n=5\right.$ per group). ${ }^{*} P<0.05,{ }^{* *} P<0.01$

solution (Innovative Cell Technologies, San Diego, CA, USA). The SKPs were then differentiated into mesenchymal precursors, as described previously. ${ }^{53}$ To obtain BMMs, bone marrow cells were collected by flushing the tibiae and femurs of 6-week-old male C57BL/6 mice. After removing the red blood cells with ACK buffer (0.01 $\mathrm{mM} \mathrm{EDTA,} 0.011 \mathrm{M} \mathrm{KHCO}_{3}$, and $0.155 \mathrm{M} \mathrm{NH}_{4} \mathrm{Cl}$, pH 7.3), the cells were cultured on 100-mm culture dishes in $\alpha$-MEM complete media containing $10 \%$ fetal bovine serum (FBS), $100 \mathrm{U} / \mathrm{ml}$ penicillin, $100 \mu \mathrm{g} / \mathrm{ml}$ streptomycin, and $10 \mathrm{ng} / \mathrm{ml}$ M-CSF. Cells that did not attach to the culture plates were incubated with $30 \mathrm{ng} / \mathrm{ml}$ mouse M-CSF for a further 3 days, and the adherent cells were used as BMMs. All procedures for obtaining human tissue specimens were reviewed and approved by the Institutional Review Board on Human Subjects Research and the Ethics Committee at Seoul National University Dental Hospital (approval number: CRI12004G).

Osteoclast differentiation assay. To generate osteoclasts from BMM cultures, BMMs $\left(2 \times 10^{5}\right.$ cells/well) were cultured for 6 days on 48 -well culture plates coated with vehicle (DMSO), vitronectin $\left(0.23 \mu \mathrm{g} / \mathrm{cm}^{2}\right)$, or synthetic peptides $\left(9.1 \mu \mathrm{g} / \mathrm{cm}^{2}\right)$, in the presence of $30 \mathrm{ng} / \mathrm{ml} \mathrm{M-CSF}$ and $100 \mathrm{ng} / \mathrm{ml}$ mouse soluble RANKL. The complete medium was changed on days 3 and 5 . After culturing, the cells were fixed and stained for TRAP-a marker enzyme of osteoclasts.

Cell attachment and spreading assays. Cell attachment assays were performed as described previously. ${ }^{54}$ Briefly, 48 -well culture plates were coated with human plasma vitronectin $\left(0.23 \mu \mathrm{g} / \mathrm{cm}^{2}\right)$ or rVn-FIl $\left(5.7 \mu \mathrm{g} / \mathrm{cm}^{2}\right)$ for $24 \mathrm{~h}$ at $4^{\circ} \mathrm{C}$. Peptides $\left(9.1 \mu \mathrm{g} / \mathrm{cm}^{2}\right)$ were also adsorbed onto plates by drying for $24 \mathrm{~h}$ at room temperature. The concentrations of the recombinant protein and synthetic peptides were determined from a dose-response curve, and the lowest concentration that achieved maximum attachment to human osteogenic cells was used. The concentration of human plasma vitronectin was determined according to the manufacturer's instructions. Substrate-coated plates were blocked with $1 \%$ heatinactivated bovine serum albumin (BSA) in phosphate-buffered saline (PBS) for $1 \mathrm{~h}$ at $37^{\circ} \mathrm{C}$, and then washed with PBS. Cells $\left(5 \times 10^{4}\right.$ cells/250 $\mu$ l) were added to each plate and incubated for $1 \mathrm{~h}$ at $37^{\circ} \mathrm{C}$. After the incubation, the unattached cells were removed by rinsing the plates twice with PBS. The attached cells were fixed with $10 \%$ formalin for 15 min and stained with $0.5 \%$ crystal violet for $1 \mathrm{~h}$. The plates were gently washed three times with double-distilled water (DDW), after which the content of each well was solubilized in 2\% SDS for $5 \mathrm{~min}$. The absorbance at 570 $\mathrm{nm}$ was measured using a microplate reader. For cell-spreading assays, the cells $\left(3 \times 10^{4} \mathrm{cells} / 250 \mu \mathrm{l}\right)$ were added to each substrate-coated plate and incubated for $3 \mathrm{~h}$ at $37^{\circ} \mathrm{C}$. The attached cells were fixed with $10 \%$ formalin and then stained with $0.5 \%$ crystal violet for $1 \mathrm{~h}$. The plates were gently washed three times with PBS. Cell spreading was assessed by measuring the surface areas of the cells with Image Pro Plus software (version 4.5; Media Cybernetics, Silver Spring, MD, USA).

Attachment inhibition assay. The cells $\left(5 \times 10^{4}\right.$ cells/250 $\mu$ l) were preincubated with $5 \mathrm{mM}$ EDTA, $500 \mu \mathrm{M} \mathrm{MnCl}, 100 \mu \mathrm{g} / \mathrm{ml}$ heparin, and $10 \mu \mathrm{g} / \mathrm{ml}$ 


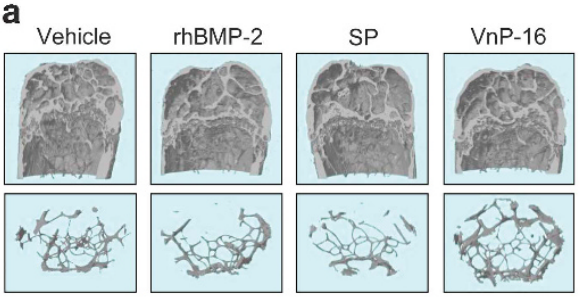

e

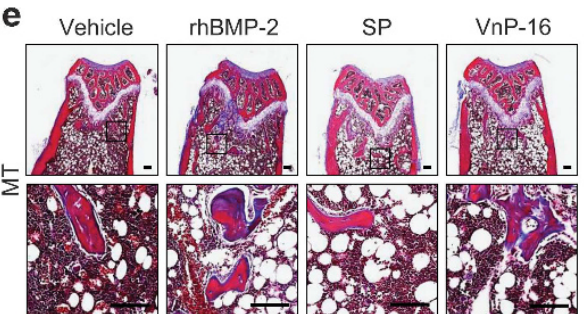

b

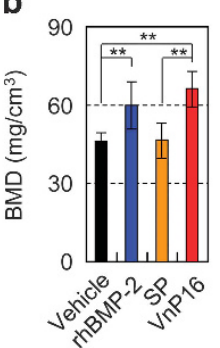

C

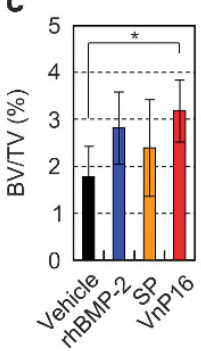

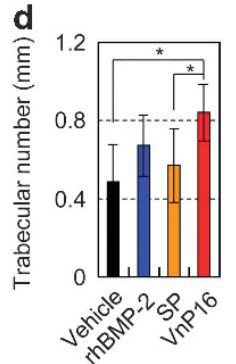

f

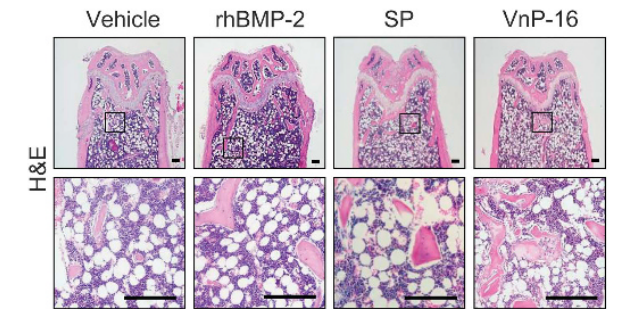

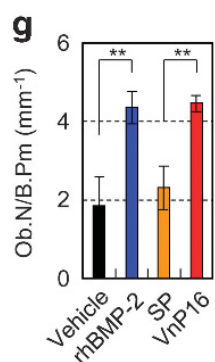

k

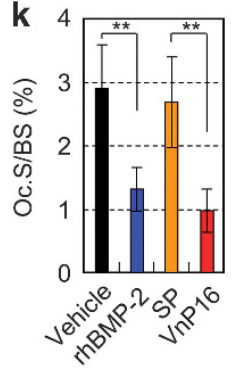

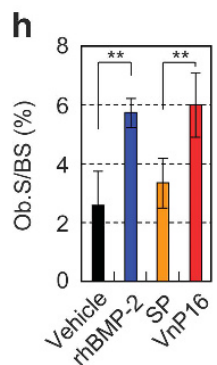

I i

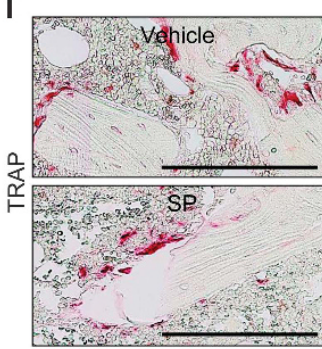

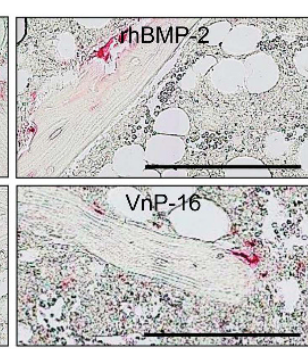

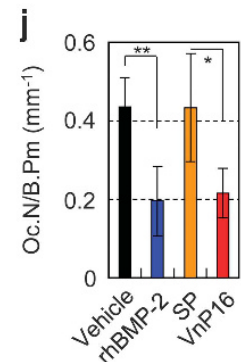

Reversing osteoporosis

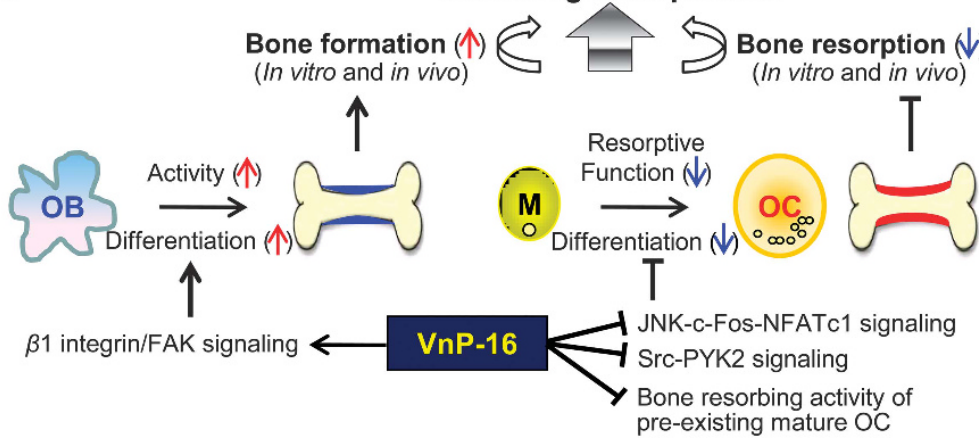

Figure 9 VnP-16 substantially alleviates osteoporosis by reversing OVX-induced bone loss. (a-d) $\mu \mathrm{CT}$ reconstruction of metaphyses of distal femurs (a) as well as BMD (b) BV/TV (c), and trabecular number (d) in OVX mice at 1 week after administration of vehicle, rhBMP-2, SP, or VnP-16. The images represent femurs (a, upper panel) and its trabecular bones (a, lower panel) of vehicle-, rhBMP-2-, or peptide-treated OVX mice. (e and f) Masson's trichrome (e) and H\&E (f) staining of femur sections from OVX mice at 1 week after administration of vehicle, rhBMP-2, SP, or VnP-16. Scale bars, $200 \mu \mathrm{m}$. ( $(\mathbf{g}$ and $\mathbf{h})$ Morphometric analysis of the osteoblast number $(\mathbf{g})$ and osteoblast surface $(\mathbf{h})$ in OVX mice at 1 week after administration of vehicle, rhBMP-2, SP, or VnP-16. (i) TRAP staining of osteoclasts surrounding trabecular bones in OVX mice at 1 week after administration of vehicle, rhBMP-2, SP, or VnP-16. Scale bars, $200 \mu \mathrm{m}$. (j and k) Morphometric analysis of the osteoclast number (j) and osteoclast surface (k) in OVX mice at 1 week after administration of vehicle, rhBMP-2, SP, or VnP-16. (I) Proposed pathway for reversing estrogen deficiency-induced bone loss by a vitronectin-derived peptide VnP-16. OB, osteoblasts; OC, osteoclasts; M, bone marrow-derived macrophages. Data in (b-d, $\mathbf{g}, \mathbf{h}, \mathbf{j}$ and $\mathbf{k}$ ) represent the mean $\pm S D\left(n=7\right.$ per group). ${ }^{*} P<0.05,{ }^{* \star} P<0.01$

function-blocking antibodies against the integrin subunits $\alpha 1$ (FB12), $\alpha 2$ (P1E6), $\alpha 3$ (P1B5), $\alpha 4$ (P4C2), $\alpha 5$ (P1D6), $\alpha 6$ (NKI-GoH3), $\beta 3$ (B3A; Chemicon, Temecula, CA, USA), $\alpha$ (AV1), or $\beta 1$ (6S6; Millipore) for $15 \mathrm{~min}$ at $37^{\circ} \mathrm{C}$. The preincubated cells were transferred to plates that were coated with $\mathrm{VnP}-16\left(9.1 \mu \mathrm{g} / \mathrm{cm}^{2}\right)$ and incubated for $1 \mathrm{~h}$ at $37^{\circ} \mathrm{C}$. The attached cells were then quantified as described elsewhere.

TUNEL assay. Apoptosis was analyzed in situ by the TUNEL assay using the In Situ Cell Death Detection Kit, Fluorescein (Roche Applied Science, Mannheim, German) according to the manufacturer's instructions. To ensure a representative count, each cell culture slide was divided into quarters, and at least two fields were photographed with Olympus BX 50 fluorescence microscope. The number of apoptotic cells was measured by counting the TUNEL-positive cells. Average number and standard deviation were calculated from four independent experiments.

Determination of peptide secondary structures. The secondary structures of the rVn-Fll truncation and $\mathrm{VnP}-16$ peptide were analyzed using the PSIPRED protein structure prediction server (http://bioinf.cs.ucl.ac.uk/psipred/). ${ }^{55}$

Histological staining. Histological staining of osteogenic cells was performed as described previously. ${ }^{56}$ Briefly, to visualize mineral deposits, the cells were fixed 
with ice-cold $95 \%$ ethanol for $30 \mathrm{~min}$ at $-20^{\circ} \mathrm{C}$, and then stained with $40 \mathrm{mM}$ Alizarin red $\mathrm{S}$ solution $(\mathrm{pH} 4.2)$ for $1 \mathrm{~h}$. The stained cells were washed five times with DDW and then rinsed with PBS for $15 \mathrm{~min}$.

Immunoblotting. Human osteogenic cells $\left(1 \times 10^{6}\right)$ were plated onto $60 \mathrm{~mm}$ dishes that had been precoated with vitronectin $\left(0.23 \mu \mathrm{g} / \mathrm{cm}^{2}\right)$ or synthetic peptides $\left(9.1 \mu \mathrm{g} / \mathrm{cm}^{2}\right)$, and allowed to adhere for $3 \mathrm{~h}$. The cells were then washed with icecold PBS and lysed with $150 \mu \mathrm{l}$ RIPA buffer (50 mM Tris-HCl, pH 7.4, $150 \mathrm{mM} \mathrm{NaCl}$, $1 \mathrm{mM}$ EDTA, $1 \%$ Triton X-100, $1 \mathrm{mM}$ PMSF, $2 \mathrm{mM} \mathrm{Na}_{3} \mathrm{VO}_{4}$, and $1 \mathrm{mM}$ glycerol phosphate) containing a protease inhibitor cocktail. The proteins present in the RIPA lysates were denatured using SDS sample buffer, resolved by SDS-PAGE, and electroblotted onto nitrocellulose membranes. The membranes were immunoblotted with primary antibodies against focal adhesion kinase (FAK; Upstate Biotechnology,

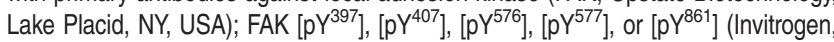
Carlsbad, CA, USA); or actin (Sigma-Aldrich, St. Louis, MO, USA). All blots were then incubated with anti-rabbit horseradish peroxidase-conjugated secondary antibodies (Cell Signaling Technology, Danvers, MA, USA). The signals were detected by electrochemiluminescence. The ratio of target protein to total protein or $\beta$-actin for each sample was then calculated to correct for differences in protein loading. This ratio was normalized to the target protein/total protein or $\beta$-actin ratio of the negative controls to obtain the relative levels of protein.

Transfection. A nonspecific control siRNA (Invitrogen), and siRNAs against human FAK (Sigma-Aldrich) or $\beta 1$ integrin (Santa Cruz Biotechnology Inc., Santa Cruz, CA, USA) were used for gene silencing. Human osteogenic cells were plated into $100 \mathrm{~mm}$ dishes at a density of $1.5 \times 10^{5}$ cells per dish, cultured for 1 day, and then transfected with 10,50 , or $100 \mathrm{nM}$ FAK siRNA, $10 \mathrm{nM} \beta 1$ integrin siRNA, or 10 or $100 \mathrm{nM}$ control siRNA using $15 \mu \mathrm{l}$ of Lipofectamine RNAiMAX transfection reagent (Invitrogen).

Pull-down assay of biotin-labeled peptide. Pull-down assays were performed as described previously ${ }^{57}$ with biotinylated SP and biotinylated VnP-16 peptides. Cells $\left(3 \times 10^{6}\right.$ cells) were seeded onto $100-\mathrm{mm}$ dishes coated with biotinconjugated peptides $\left(9.1 \mu \mathrm{g} / \mathrm{cm}^{2}\right)$ for $30 \mathrm{~min}$ and washed twice with cold PBS. Cells were scraped with $500 \mu$ l lysis buffer $(50 \mathrm{mM}$ Tris- $\mathrm{HCl}, \mathrm{pH} 7.5,150 \mathrm{mM} \mathrm{NaCl}, 0.1 \%$ sodium deoxycholate, $1 \%$ Triton $\mathrm{X}-100$, protease, and phosphatase inhibitor cocktail tablets), followed by passing the lysates 15 times through a 26.5-gauge needle and then spinning at $17,000 \times g$ for $10 \mathrm{~min}$ at $4^{\circ} \mathrm{C}$. The supernatants were incubated with $60 \mu$ l of streptavidin agarose beads (Thermo Scientific, Rockford, IL, USA) for $16 \mathrm{~h}$ at $4{ }^{\circ} \mathrm{C}$ and spun at $1,500 \times \mathrm{g}$ for $2 \mathrm{~min}$ at $4^{\circ} \mathrm{C}$. After washing the beads four times with lysis buffer, the precipitated proteins were resolved by $8 \%$ SDS-PAGE and analyzed by immunoblotting.

TRAP staining. The TRAP assay was performed using the Leukocyte Acid Phosphatase Assay Kit (Sigma-Aldrich), according to the manufacturer's instructions. Briefly, the cells were washed, fixed with $10 \%$ formalin, and stained with $40 \mathrm{mM}$ sodium tartrate. TRAP-positive multinucleated cells containing more than three nuclei were considered to be osteoclasts.

Bone resorption assay. Mature osteoclasts were prepared from co-cultures of bone marrow cells and primary osteoblasts on collagen gel-coated culture dishes, as described previously. ${ }^{58}$ For the bone resorption assay, BMMs and mature osteoclasts were cultured on Osteo Assay Surface plates (Corning) for 6 days and $12 \mathrm{~h}$, respectively, coated with vehicle (DMSO), vitronectin $\left(0.23 \mu \mathrm{g} / \mathrm{cm}^{2}\right)$, or synthetic peptide $\left(9.1 \mu \mathrm{g} / \mathrm{cm}^{2}\right)$ in the presence of $30 \mathrm{ng} / \mathrm{ml} \mathrm{M-CSF}$ and $100 \mathrm{ng} / \mathrm{ml}$ RANKL. The cells were removed using $10 \%$ Clorox $(0.56 \% \mathrm{NaOCl})$, and the resorbed pits were photographed and analyzed using the Image Pro-Plus program (version 4.0; Media Cybernetics).

Animal experiments. Critical-sized calvarial defects were generated in 8week-old male Sprague-Dawley rats $(n=5$ per group). Absorbable collagen sponges (BiolandKorea, Cheonan, Korea) were loaded with rhBMP-2 $(2 \mu \mathrm{g}$ per scaffold, $15 \mu$ l volume; Pepro-Tech, Rocky Hill, NJ, USA), synthetic peptides (1 mg per scaffold, $15 \mu \mathrm{l}$ volume), or vehicle ( $10 \mu \mathrm{l}$ of DMSO and $5 \mu \mathrm{l}$ of DDW). The surgical procedures to perforate an $8 \mathrm{~mm}$ circular defect in the parietal bone and implantation of the collagen sponge were performed as described previously. ${ }^{38}$ The rats were euthanized 2 weeks after surgery, and whole calvariae were fixed in $4 \%$ paraformaldehyde for $24 \mathrm{~h}$ at $4{ }^{\circ} \mathrm{C}$ and then analyzed by $\mu \mathrm{CT}$ scanning. For histomorphometric analysis, the specimens were decalcified with $12 \%$ EDTA for
4 weeks and embedded in paraffin. The paraffin-embedded samples were sectioned at a thickness of $4 \mu \mathrm{m}$ and then stained with Masson's trichrome.

To study the effects of VnP-16 on IL- $1 \alpha$-induced mouse calvarial bone loss, dried collagen sponges loaded with IL-1 $\alpha(2 \mu \mathrm{g})$, synthetic peptides $(125 \mu \mathrm{g})$, synthetic peptides (125 $\mu \mathrm{g})$ plus IL-1 $\alpha(2 \mu \mathrm{g})$, or vehicle (DMSO) were implanted over the calvarial bones of 5 -week-old male ICR mice ( $n=5$ per group). The mice were sacrificed on day 7 and the whole calvariae were dissected, cleaned of soft tissue, and fixed in $4 \%$ paraformaldehyde for $24 \mathrm{~h}$ at $4{ }^{\circ} \mathrm{C}$. TRAP staining and $\mu \mathrm{CT}$ scanning were then performed.

To study the effects of VnP-16 on OVX-induced bone loss in mice, female C57BL/6 mice were ovariectomized at 8 weeks of age. The mice were maintained under standard animal housing conditions (12-h light 12-h dark cycles and free access to food and water). At 12 weeks after surgery, rhBMP-2, synthetic peptides, or vehicle was injected intrafemorally after anesthetizing the mice with an intraperitoneal injection of a mix of $31.25 \mathrm{mg} / \mathrm{kg}$ tiletamine/zolazepam and $8.75 \mathrm{mg} / \mathrm{kg}$ xylazine ( $n=7$ per group). Both hind limbs were shaved and sterilized with $70 \%$ ethanol. The knee was held in a flexed position, and a total volume of $5 \mu \mathrm{l}$ of rhBMP-2 $(2 \mu \mathrm{g})$, synthetic peptides $(50 \mu \mathrm{g})$, or vehicle $(50 \% \mathrm{DMSO})$ was injected intrafemorally through the knee joint into the medullary cavity using a $10 \mu \mathrm{l}$ Hamilton syringe and a 31-gauge needle. The needle was withdrawn and the leg immediately straightened and held straight for $\sim 1 \mathrm{~min}$. The mice were killed on day 7 , and the bilateral femurs were dissected, cleaned of soft tissue, and fixed in $4 \%$ paraformaldehyde at $4{ }^{\circ} \mathrm{C}$ for the subsequent ex vivo analysis. TRAP staining and $\mu \mathrm{CT}$ scanning were then performed.

The $\mu \mathrm{CT}$ scans were performed using the Micro-CT Skyscan 1172 system (70 kV, $141 \mu \mathrm{A}$, and 38 min integration time; SkyScan, Kontich, Belgium). The scans were integrated into 3D voxel images ( $2000 \times 1048$ pixel matrices), and bone images were reconstructed using the NRecon program (version 1.6.9.8; Bruker microCT, Kontich, Belgium). The regenerated bone volume, BMD, and bone mineral content were calculated with CT-Analyser (version 1.14.4.1; Bruker-microCT). The bone recovery rate $(\%)$ and calvarial thickness $(\mathrm{mm})$ were also calculated using CT-Analyser according to standardized protocols. H\&E, TRAP, and Masson's trichrome staining were performed with $5-\mu \mathrm{m}$ paraffin sections. The percentage of the osteoclast surface and the osteoclast number were calculated with OsteoMeasure XP (version 1.01; OsteoMetrics, Decatur, GA, USA), according to standardized protocols. All animal procedures were reviewed and approved by the animal care committee of the Institute of Laboratory Animal Resources of Seoul National University (approval numbers: SNU-130204-1-2, SNU-140917-3, and SNU-151104-4).

Statistical analyses. All data are presented as the mean \pm SD. The statistical analyses were performed using the STATISTICA 6.0 software package (StatSoft, Tulsa, OK, USA). Results were compared using analysis of variance tests. When significant differences were found, pairwise comparisons were performed using Scheffé's adjustment. Statistical significance was also calculated using a two-tailed Student's $t$-test. A $P$ value of $<0.05$ was considered significant.

\section{Conflict of Interest}

The authors declare no conflict of interest.

Acknowledgements. We thank Won Jong Jin (Seoul National University) for useful discussions and technical assistance. This work was supported by the Midcareer Researcher Program through a grant from the National Research Foundation of Korea, funded by the Ministry of Science, ICT and Future Planning, Korea government (2016R1A2B2007246), and the Korea Healthcare Technology R\&D Project, funded by the Ministry for Health, Welfare \& Family Affairs, Republic of Korea (HI15C2455; to B-MM).

1. Schieker M, Mutschler W. Bridging posttraumatic bony defects. Established and new methods. Unfallchirurg 2006; 109: 715-732.

2. Yaszemski MJ, Payne RG, Hayes WC, Langer R, Mikos AG. Evolution of bone transplantation: molecular, cellular and tissue strategies to engineer human bone. Biomaterials 1996; 17: 175-185.

3. Wiesmann HP, Joos U, Meyer U. Biological and biophysical principles in extracorporal bone tissue engineering. Part II. Int J Oral Maxillofac Surg 2004; 33: 523-530.

4. Tanaka S, Nakamura K, Takahasi N, Suda T. Role of RANKL in physiological and pathological bone resorption and therapeutics targeting the RANKL-RANK signaling system. Immunol Rev 2005; 208: 30-49. 
5. Broadhead ML, Clark JC, Dass CR, Choong PF, Myers DE. Therapeutic targeting of osteoclast function and pathways. Expert Opin Ther Targets 2011; 15: 169-181.

6. Kim SH, Moon SH. Osteoclast differentiation inhibitors: a patent review (2008 - 2012). Expert Opin Ther Pat 2013; 23: 1591-1610.

7. Looker AC, Borrud LG, Dawson-Hughes B, Shepherd JA, Wright NC. Osteoporosis or low bone mass at the femur neck or lumbar spine in older adults: United States, 2005-2008. NCHS Data Brief 2012; 93: 1-8.

8. Wright NC, Looker AC, Saag KG, Curtis JR, Delzell ES, Randall S et al. The recent prevalence of osteoporosis and low bone mass in the United States based on bone mineral density at the femoral neck or lumbar spine. J Bone Miner Res 2014; 29: 2520-2526.

9. Park SB, Park SH, Kim NH, Chung CK. BMP-2 induced early bone formation in spine fusion using rat ovariectomy osteoporosis model. Spine J 2013; 13: 1273-1280.

10. Craik DJ, Fairlie DP, Liras S, Price D. The future of peptide-based drugs. Chem Biol Drug Des 2013; 81: 136-147.

11. Bose S, Roy M, Bandyopadhyay A. Recent advances in bone tissue engineering scaffolds. Trends Biotechnol 2012; 30: 546-554

12. Takasaki W, Kajino Y, Kajino K, Murali R, Greene Ml. Structure-based design and characterization of exocyclic peptidomimetics that inhibit TNF $\alpha$ binding to its receptor. Nat Biotechnol 1997; 15: 1266-1270.

13. Aoki K, Alles N, Soysa N, Ohya K. Peptide-based delivery to bone. Adv Drug Deliv Rev2012; 64: $1220-1238$

14. Dettin M, Bagno A, Morpurgo M, Cacchioli A, Conconi MT, Di Bello C et al. Evaluation of silicon dioxide-based coating enriched with bioactive peptides mapped on human vitronectin and fibronectin: in vitro and in vivo assays. Tissue Eng 2006; 12: 3509-3523.

15. Lee JY, Choi YS, Lee SJ, Chung CP, Park YJ. Bioactive peptide-modified biomaterials for bone regeneration. Curr Pharm Des 2011; 17: 2663-2676.

16. Molek P, Strukelj B, Bratkovic T. Peptide phage display as a tool for drug discovery: targeting membrane receptors. Molecules 2011; 16: 857-887.

17. Slingluff CL Jr.. The present and future of peptide vaccines for cancer: single or multiple, long or short, alone or in combination? Cancer J 2011; 17: 343-350.

18. Whitfield JF, Morley P, Willick GE. Parathyroid hormone, its fragments and their analogs for the treatment of osteoporosis. Treat Endocrinol 2002; 1: 175-190.

19. Subbiah V, Madsen VS, Raymond AK, Benjamin RS, Ludwig JA. Of mice and men: divergent risks of teriparatide-induced osteosarcoma. Osteoporos Int 2010; 21: 1041-1045.

20. Zhao Q, Wang X, Liu Y, He A, Jia R. NFATc1: functions in osteoclasts. Int J Biochem Cell Biol 2010; 42: 576-579.

21. Nakashima T, Hayashi M, Takayanagi $H$. New insights into osteoclastogenic signaling mechanisms. Trends Endocrinol Metab 2012; 23: 582-590.

22. Soysa NS, Alles N, Aoki K, Ohya K. Osteoclast formation and differentiation: an overview. J Med Dent Sci 2012; 59: 65-74.

23. Lacey DL, Timms E, Tan HL, Kelley MJ, Dunstan CR, Burgess T et al. Osteoprotegerin ligand is a cytokine that regulates osteoclast differentiation and activation. Cell 1998; 93: 165-176.

24. Xiong J, Onal M, Jilka RL, Weinstein RS, Manolagas SC, O'Brien CA. Matrix-embedded cells control osteoclast formation. Nat Med 2011; 17: 1235-1241.

25. Takayanagi H, Kim S, Koga T, Nishina H, Isshiki M, Yoshida H et al. Induction and activation of the transcription factor NFATc1 (NFAT2) integrate RANKL signaling in terminal differentiation of osteoclasts. Dev Cell 2002; 3: 889-901.

26. Takayanagi H. Osteoimmunology: shared mechanisms and crosstalk between the immune and bone systems. Nat Rev Immunol 2007; 7: 292-304.

27. Nakashima T, Takayanagi $H$. The dynamic interplay between osteoclasts and the immune system. Arch Biochem Biophys 2008; 473: 166-171.

28. Asagiri M, Sato $\mathrm{K}$, Usami $\mathrm{T}$, Ochi $\mathrm{S}$, Nishina $\mathrm{H}$, Yoshida $\mathrm{H}$ et al. Autoamplification of NFATc1 expression determines its essential role in bone homeostasis. J Exp Med 2005; 202: 1261-1269.

29. Aliprantis AO, Ueki Y, Sulyanto R, Park A, Sigrist KS, Sharma SM et al. NFATc1 in mice represses osteoprotegerin during osteoclastogenesis and dissociates systemic osteopenia from inflammation in cherubism. J Clin Invest 2008; 118: 3775-3789.

30. Duong LT, Lakkakorpi PT, Nakamura I, Machwate M, Nagy RM, Rodan GA. PYK2 in osteoclasts is an adhesion kinase, localized in the sealing zone, activated by ligation of $\alpha_{v} \beta_{3}$ integrin, and phosphorylated by src kinase. J Clin Invest 1998; 102: 881-892.

31. Boron WF, Boulpaep EL (eds). Medical Physiology. Saunders: New York, NY, USA, 2012.

32. Cherny RC, Honan MA, Thiagarajan P. Site-directed mutagenesis of the arginine-glycineaspartic acid in vitronectin abolishes cell adhesion. J Biol Chem 1993; 268: 9725-9729.

33. Shin TM, Isas JM, Hsieh CL, Kayed R, Glabe CG, Langen R et al. Formation of soluble amyloid oligomers and amyloid fibrils by the multifunctional protein vitronectin. Mol Neurodegener 2008; 3: 16.
34. Hynes RO. Integrins: versatility, modulation, and signaling in cell adhesion. Cell 1992; 69: $11-25$.

35. Mandicourt G, Iden S, Ebnet K, Aurrand-Lions M, Imhof BA. JAM-C regulates tight junctions and integrin-mediated cell adhesion and migration. J Biol Chem 2007; 282: 1830-1837.

36. Owen JD, Ruest PJ, Fry DW, Hanks SK. Induced focal adhesion kinase (FAK) expression in FAK-null cells enhances cell spreading and migration requiring both auto- and activation loop phosphorylation sites and inhibits adhesion-dependent tyrosine phosphorylation of Pyk2. Mol Cell Biol 1999; 19: 4806-4818.

37. Slack-Davis JK, Martin KH, Tilghman RW, Iwanicki M, Ung EJ, Autry C et al. Cellular characterization of a novel focal adhesion kinase inhibitor. J Biol Chem 2007; 282: 14845-14852.

38. Lee JH, Kim CS, Choi KH, Jung UW, Yun JH, Choi SH et al. The induction of bone formation in rat calvarial defects and subcutaneous tissues by recombinant human BMP-2, produced in Escherichia coli. Biomaterials 2010; 31: 3512-3519.

39. Huang H, Chang EJ, Ryu J, Lee ZH, Lee Y, Kim HH. Induction of c-Fos and NFATc1 during RANKL-stimulated osteoclast differentiation is mediated by the p38 signaling pathway. Biochem Biophys Res Commun 2006; 351: 99-105.

40. Yamashita T, Yao Z, Li F, Zhang Q, Badell IR, Schwarz EM et al. NF-kB p50 and p52 regulate receptor activator of NF-kB ligand (RANKL) and tumor necrosis factor-induced osteoclast precursor differentiation by activating c-Fos and NFATc1. J Biol Chem 2007; 282: 18245-18253.

41. Lakkakorpi PT, Bett AJ, Lipfert L, Rodan GA, Duong LT. PYK2 autophosphorylation, but no kinase activity, is necessary for adhesion-induced association with c-Src, osteoclast spreading, and bone resorption. J Biol Chem 2003; 278: 11502-11512.

42. Izawa T, Zou W, Chappel JC, Ashley JW, Feng X, Teitelbaum SL. c-Src links a RANK/ $/$ v $\beta 3$ integrin complex to the osteoclast cytoskeleton. Mol Cell Biol 2012; 32: 2943-2953.

43. Zou W, Kitaura H, Reeve J, Long F, Tybulewicz VL, Shattil SJ et al. Syk, c-Src, the $\alpha v \beta 3$ integrin, and ITAM immunoreceptors, in concert, regulate osteoclastic bone resorption. J Cell Biol 2007; 176: 877-888.

44. Polimeni G, Xiropaidis AV, Wikesjo UM. Biology and principles of periodontal wound healing/ regeneration. Periodontol 2000 2006; 41: 30-47.

45. Villar CC, Cochran DL. Regeneration of periodontal tissues: guided tissue regeneration Dent Clin North Am 2010; 54: 73-92.

46. Richardson A, Parsons T. A mechanism for regulation of the adhesion-associated protein tyrosine kinase pp125 $5^{\mathrm{FAK}}$. Nature 1996; 380: 538-540.

47. Soriano P, Montgomery C, Geske R, Bradley A. Targeted disruption of the c-src protooncogene leads to osteopetrosis in mice. Cell 1991; 64: 693-702.

48. Yu B, Chang J, Liu Y, Li J, Kevork K, Al-Hezaimi K et al. Wnt4 signaling prevents skeletal aging and inflammation by inhibiting nuclear factor-кB. Nat Med 2014; 20 : 1009-1017.

49. Weitzmann MN, Pacifici R. Estrogen deficiency and bone loss: an inflammatory tale. J Clin Invest 2006; 116: 1186-1194.

50. Min BM, Lee G, Kim SH, Nam YS, Lee TS, Park WH. Electrospinning of silk fibroin nanofibers and its effect on the adhesion and spreading of normal human keratinocytes and fibroblasts in vitro. Biomaterials 2004; 25: 1289-1297.

51. Yeo IS, Oh JE, Jeong L, Lee TS, Lee SJ, Park WH et al. Collagen-based biomimetic nanofibrous scaffolds: preparation and characterization of collagen/silk fibroin bicomponent nanofibrous structures. Biomacromolecules 2008; 9: 1106-1116.

52. Toma JG, Akhavan M, Fernandes KJ, Barnabe-Heider F, Sadikot A, Kaplan DR et al. Isolation of multipotent adult stem cells from the dermis of mammalian skin. Nat Cell Bio 2001; 3: 778-784.

53. Fernandes KJ, McKenzie IA, Mill P, Smith KM, Akhavan M, Barnabe-Heider F et al. A dermal niche for multipotent adult skin-derived precursor cells. Nat Cell Biol 2004; 6 . 1082-1093.

54. Kim JM, Park WH, Min BM. The PPFLMLLKGSTR motif in globular domain 3 of the human laminin- $5 \alpha 3$ chain is crucial for integrin $\alpha 3 \beta 1$ binding and cell adhesion. Exp Cell Res 2005 304: 317-327.

55. McGuffin LJ, Bryson K, Jones DT. The PSIPRED protein structure prediction server. Bioinformatics 2000; 16: 404-405.

56. Lavoie JF, Biernaskie JA, Chen Y, Bagli D, Alman B, Kaplan DR et al. Skin-derived precursors differentiate into skeletogenic cell types and contribute to bone repair. Stem Cells Dev 2009; 18: 893-905

57. Böttcher RT. $\beta 1$ integrin cell-surface immunoprecipitation (selective immunoprecipitation). Bioprotocol 2013; 3: e962.

58. Lee JH, Kim HN, Yang D, Jung K, Kim HM, Kim HH et al. Trolox prevents osteoclastogenesis by suppressing RANKL expression and signaling. J Biol Chem 2009; 284: 13725-13734.

Supplementary Information accompanies this paper on Cell Death and Differentiation website (http://www.nature.com/cdd) 